\title{
Fluorescent dissolved organic matter as a multivariate biogeochemical tracer of submarine groundwater discharge in coral reef ecosystems.
}

\author{
Craig E. Nelson ${ }^{*}$, Megan J. Donahue $e^{\mathrm{b}}$ Henrieta Dulaiovac, Stuart J. Goldberga, \\ Florybeth F. La Valleb, Katie Lubarskyb, Justin Miyanob, Christina Richardson ${ }^{\mathrm{c}}$, Nyssa \\ J. Silbigerb and Florence I.M. Thomas ${ }^{b}$ \\ aCenter for Microbial Oceanography: Research and Education, Department of \\ Oceanography and Sea Grant College Program, School of Ocean and Earth Science \\ and Technology, University of Hawai'i at Mānoa, Honolulu, Hawai'i, USA 96822. \\ bHawai'i Institute of Marine Biology, School of Ocean and Earth Science and \\ Technology, University of Hawai'i at Mānoa, Honolulu, Hawai' i, USA 96822. \\ cDepartment of Geology and Geophysics, School of Ocean and Earth Science and \\ Technology, University of Hawai'i at Mānoa, Honolulu, Hawai'i, USA 96822. \\ *corresponding author - craig.nelson@hawaii.edu
}




\section{Abstract}

2 In Hawai'i and other Pacific high islands submarine groundwater discharge (SGD)

3 can be a significant and continuous source of solutes to nearshore reefs and may

4 play a key role in the structure and function of benthic coral and algal communities.

5 Identifying SGD sources and linking them to reef biogeochemistry is technically

6 challenging. Here we analyzed spectra of fluorescent dissolved organic matter

7 (fDOM) in coral reefs in the context of a suite of biogeochemical parameters along

8 gradients of SGD to characterize fDOM composition and evaluate the utility of fDOM

9 signatures in tracking groundwater dispersal and transformation. We spatially

10 mapped water column chemistry in Maunalua Bay, O'ahu, Hawai'i by collecting 24

11 water samples in grids at each of two $\sim 0.15 \mathrm{~km}^{2}$ regions during both high and low

12 tides over a two-day period. We observed clear horizontal gradients in the majority

13 of 15 measured parameters, including inorganic and organic solutes and organic

14 particles that tracked concentrations of conservative SGD tracers (radon, salinity

15 and silicate). Multivariate scanning excitation-emission fluorometry successfully

16 differentiated two distinct groundwater sources and delineated regions of SGD

17 dispersion in each reef from the surrounding water column samples without

18 detectable groundwater. Groundwater was consistently depleted in DOC and

19 enriched in nutrients; although the two SGD sources varied widely in fDOM quantity

20 and fluorophore proportions, indices of humification were consistently elevated in

21 SGD at both sites. Our results provide a robust spectral characterization of fDOM in

22 SGD-influenced coral reefs and indicate the potential for this rapid and cost-effective

23 measurement technique to be useful in tracking SGD dispersal in nearshore

24 ecosystems. 


\section{Introduction}

2 Coastal ecosystems experience dynamic inputs of material from benthic, fluvial,

3 groundwater and offshore habitats. Groundwater can be a significant and

4 continuous source of solutes to nearshore reefs and may play a key role in the

5 structure and function of benthic coral and macroalgal communities, as well as

6 influencing local coastal oceanography and planktonic communities. Groundwater

7 nutrient and organic matter pollution, whether through agricultural fertilization, on-

8 site sewage disposal or runoff from industrial/urban land uses, is a major

9 eutrophication concern for coral reefs because of their adaptation to relatively low

10 nutrient conditions (Fabricius, 2005; Lapointe, 1997). However, identifying

11 groundwater sources and linking them to reef biogeochemistry is technically

12 challenging.

14 Coral reefs are highly productive ecosystems adapted to oligotrophic oceans, and it

15 remains an open question how they acquire sufficient macro- and micro-nutrients

16 to maintain high productivity in low-nutrient waters (e.g., Alldredge et al., 2013).

17 Submarine groundwater discharge (SGD) is a phenomenon common to the Hawaiian

18 Islands (Dollar and Atkinson, 1992; Johnson et al., 2008; Street et al., 2008;

19 Swarzenski et al., 2013) and other Pacific high islands (Kim et al., 2011) wherein

20 groundwater is continuously and directly discharged into shallow coastal reef

21 ecosystems. SGD is assumed to be a fundamental feature of reef ecosystems where

22 fluxes are significant (Cyronak et al., 2014; Paytan et al., 2006), and tracking the rate

23 and extent of groundwater dispersion in coastal regions has been an area of

24 significant active research in Hawai'i and elsewhere (Johnson et al., 2008; Knee et

25 al., 2010; Moore, 2010; Street et al., 2008). Current techniques to understand where

26 and when SGD is diffused throughout the nearshore habitat include thermal imaging

27 (Johnson et al., 2008), dye tracer studies (Burnett et al., 2006), geophysical

28 exploration (Dimova et al., 2012), radioisotopic tracers (Charette et al., 2008), and

29 mapping of conservative solute concentrations (Street et al., 2008). 
31 The influence of SGD on the structure and function of coral reefs is poorly

32 understood. The elevated levels of nitrate and phosphate found in SGD in many

33 regions of Hawai'i (Johnson et al., 2008; Knee et al., 2010; Street et al., 2008) have

34 been implicated as a key factor in coastal eutrophication (Dailer et al., 2010),

35 changes in benthic algal composition (Smith et al., 2010; Stimson and Larned, 2000)

36 and alteration of nearshore plankton biomass and community structure (Fabricius,

37 2005; McCook, 1999; Parsons et al., 2008). Despite our conceptualization of SGD as

38 driving eutrophication, we have few studies mapping the distribution of organic

39 matter in the water column of reefs experiencing significant SGD inputs (Tedetti et

40 al., 2011). A key question for the role of SGD in coral ecosystems is how SGD may

41 influence the organic composition of coral reefs, both through allochthonous

42 subsidies and through stimulation of autochthonous productivity.

44 Dissolved organic matter (DOM) in aquatic ecosystems is a significant component of

45 the total organic content of marine ecosystems. The pool of DOM in the oceans is

46 vast, containing carbon equivalent to the $\mathrm{CO}_{2}$ in the Earth's atmosphere, and

47 compositionally complex, with degradation time scales that vary greatly from hours

48 to many years (Hansell and Carlson, 2014). A portion of DOM fuels food webs

49 through metabolism by single-celled osmotrophs such as heterotrophic Bacteria and

50 Archaea that are subsequently grazed by microbial eukaryotes, a process known as

51 the "microbial loop" (Azam et al., 1983). The organic matter content of groundwater

52 can vary widely depending on the geological and hydrological factors defining

53 groundwater catchments and biogeochemical processes altering solutes within the

54 subterranean estuary (STE) (Kim et al., 2012). SGD in island systems can be sourced

55 from a variety of different ages and levels of human impact (Knee et al., 2010;

56 Wolanski et al., 2009), and little is known about the characteristics of groundwater

57 organic matter in Pacific islands (Tedetti et al., 2011). SGD passes through the STE,

58 a biogeochemical reactor that is analogous in metabolic complexity to surface

59 estuaries where terrestrial freshwater and recirculated seawater mix, differing

60 markedly with regards to sunlight exposure, residence time and redox conditions.

61 The sources of DOM in the STE can be diverse and include terrestrial inputs (Tedetti 
62 et al., 2011), locally produced DOM within the STE (Santos et al., 2009), and marine

63 DOM, which enters the STE via seawater recirculating through the coastal aquifer

64 (Beck et al., 2007; Goñi and Gardner, 2003; Kim et al., 2012). Direct allochthonous

65 DOM subsidies from SGD may have varying degrees of lability relative to ambient

66 DOM depending on age and composition (Burdige et al., 2004; Kim et al., 2012); if

67 allochthonous DOM in SGD is labile, it could stimulate the microbial loop in reefs

68 thereby supporting a portion of the reef food web. Autochthonous production

69 stimulated by SGD nutrient subsidies may also produce labile DOM that supports

70 higher trophic levels (Johnson and Wiegner, 2013; Lee et al., 2010). Both subsidies

71 of DOM may have significant impacts on reef ecosystem function, and understanding

72 the relationship between SGD and DOM in reefs is an important step toward

73 understanding how SGD influences reef ecosystems and how groundwater

74 contamination may alter ecosystems processes.

75

76 The composition of DOM in aquatic environments is known to be highly complex,

77 comprising a diverse suite of thousands of molecules ranging in molecular weight

78 across many orders of magnitude (Hansell and Carlson, 2014). One method of

79 characterizing DOM is through spectral analysis of a subset of DOM that exhibits

80 autofluorescence, typically stimulated by ultraviolet and blue light (Coble, 1996).

81 This fluorescent DOM (fDOM) can exhibit variable fluorescence across a range of

82 excitation and emission wavelengths, and scanning fluorescence spectroscopy can

83 produce a three dimensional map of the fDOM in a sample that varies through space

84 and time according to subtle shifts in chemical composition of the complex

85 molecular assemblage (Nelson and Coble, 2009). Analysis of the multivariate

86 spectral characteristics of fDOM by generating an excitation-emission matrix (EEM)

87 from a sample is a cost-effective analysis that requires minimal laboratory training

88 and equipment and can produce a suite of informative data about the organic matter

89 chemistry of the water. In marine ecosystems, the variation in fDOM characteristics

90 has been used to differentiate between a variety of DOM sources including

91 terrestrial (Coble, 1996), algal (Determann et al., 1998), microbial (Stedmon and

92 Markager, 2005) and anthropogenic (Dabestani and Ivanov, 1999; Ferretto et al., 
93 2014). Additionally, fDOM characterization has proven useful in differentiating

94 contributions from rivers, groundwater, coastal margins and reefs, and the open

95 ocean (Chen et al., 2003; Helms et al., 2013; Osburn et al., 2013; Tedetti et al., 2011).

96 If fDOM exhibits clearly defined characteristics across gradients of SGD influence it

97 has the potential to serve as a promising tool for understanding the role of

98 groundwater in reef ecosystems.

100 The present study sought to examine the relationship between SGD inputs and the

101 field of particulate, dissolved and fluorescent organics in coral reef ecosystems. We

102 identified two regions of a single contiguous reef system with relatively predictable

103 nearshore inputs of SGD (Maunalua Bay, O'ahu, Hawai'i), which range from 12,000

104 to $16,000 \mathrm{~m}^{3} \mathrm{~d}^{-1}$ (Holleman, 2011). SGD here is composed of brackish groundwater

105 (salinity 2-5) discharging through channelized groundwater conduits (Dimova et al.,

106 2012) thus bypassing STE processes typical for tidal flats. Since the water contains

107 minimal recirculated seawater and an extensive STE is absent, its terrestrial DOM

108 signature is preserved making it a unique SGD tracer. We first mapped the extent of

109 SGD by collecting water samples in a grid centered on an identified spring discharge

110 site at low and high tide and measuring a suite of inorganic solute concentrations,

111 including relatively conservative groundwater tracers (salinity, radon and silicate)

112 and various chemical species of $\mathrm{N}$ and P. From these same water samples we

113 collected a suite of dissolved and particulate organic matter samples, including bulk

114 measurements of DOM, particulate organic $\mathrm{C}$ and $\mathrm{N}$, chlorophyll and cytometric

115 counts of picoplankton and bacterioplankton. We tested whether these parameters

116 correlated spatially and by site with the inorganic solutes measured, examining if

117 samples from different regions of the reef clustered together in patterns consistent

118 with SGD influence on the organic matter field. Finally, we conducted spectral

119 analyses on FDOM to understand the characteristics of fDOM in different

120 groundwater sources and evaluate the potential for tracking SGD dispersal and

121 alteration across the reef ecosystem. Our results demonstrate that SGD in coral reef

122 habitats alters not only the composition of inorganic solutes such as salinity, silicate

123 and nutrients, but also bulk concentrations of dissolved and particulate organics and 
124 the spectral characteristics of fDOM. We discuss the potential for fDOM

125 measurements to be developed into a cost-effective tool for tracking SGD in similar

126 coral reefs dominated by spring groundwater inputs.

127 Methods

128

129 Water collection

130 We collected water samples at each of two nearshore fringing coral reef sites within

131 Maunalua Bay, O'ahu, Hawai'i (Figure 1a) over a two day period; 24 samples were

132 collected near Wailupe Beach Park on 28 May 2014 and 24 samples were collected

133 at Black Point on 29 May 2014 (Figure 1b,c). The majority of samples (32 of 48)

134 were collected synoptically during morning low tides $(-6$ to $-9 \mathrm{~cm})$ with an

135 additional subset (16) collected during afternoon high tides (+67 cm; Fig. S1).

136 Depths at these sites are generally $<2 \mathrm{~m}$, and the majority of samples (38) were

137 collected from the surface $(0.2 \mathrm{~m}$ below sea level); a subset of samples were

138 additionally collected from bottom waters (roughly $0.2 \mathrm{~m}$ above the benthos). Using

139 kayaks, surface water samples were hand-collected into $5 \mathrm{~L}$ high-density

140 polyethylene carboys (73062, US Plastics, Lima, OH, USA); bottom water samples

141 were collected in $5 \mathrm{~L}$ horizontal Niskin samplers $(101005 \mathrm{H}$, General Oceanics,

142 Miami, FL, USA) and immediately siphoned to carboys for processing. Carboys and

143 Niskin samplers were previously conditioned with seawater, soaked overnight in

$14410 \% \mathrm{HCl}$, thoroughly rinsed with low-organic deionized water (DIW; Barnstead

145 Nanopure Diamond, Thermo Fisher Scientific, Asheville, NC, USA) and stored dry

146 before sampling. All sample containers were also triple-rinsed with sample water

147 before filling. All filtration and subsampling of water was done on site within $2 \mathrm{~h}$ of

148 collection.

150 Sample collection and storage

151 All storage vials were acid soaked, thoroughly rinsed with DIW, air dried, and then

152 triple rinsed with sample water before collection. Samples for total alkalinity (TA)

153 were collected first directly from the carboy spigot. Duplicate TA samples $(125 \mathrm{~mL}$

154 each) were transferred into polypropylene sample bottles (Huang et al., 2012) and 
155 amended with $50 \mu \mathrm{L}$ of half-saturated $\mathrm{HgCl}_{2}$. All subsequent samples were

156 transferred to long-term storage vials via gentle $\left(1 \mathrm{~mL} \mathrm{~s}^{-1}\right)$ peristaltic pumping

157 directly from the carboy through platinum-cured silicone tubing over a period of

158 roughly $1 \mathrm{~h}$. For dissolved nutrient analyses, the filtrate from a $0.2 \mu \mathrm{m}$

159 polyethersulfone filter (Sterivex, Millipore, Billerica, MA, USA) was collected in acid-

160 washed and sample rinsed $50 \mathrm{~mL}$ polypropylene tubes and frozen to $-20^{\circ} \mathrm{C}$.

161 Samples for fDOM analysis were collected from the $0.2 \mu \mathrm{m}$ polyethersulfone filtrate

162 (after a minimum of $250 \mathrm{~mL}$ sample flushing to avoid filter DOM leaching) in amber

163 glass vials with teflon-lined septate caps (acid-washed and DIW rinsed) and stored

164 in a dark refrigerator free of volatile organics. For dissolved organic carbon (DOC)

165 analyses the filtrate from glass fiber filters (Whatman GF/F, GE Life Sciences,

166 Pittsburgh, PA, USA) was collected in glass vials with teflon-lined septate caps (acid-

167 washed and DIW rinsed) and frozen to $-20^{\circ} \mathrm{C}$ in an organic-free freezer. All glass

168 vials and filters were pre-combusted within days of sampling $\left(2 \mathrm{~h}\right.$ at $\left.400{ }^{\circ} \mathrm{C}\right)$ and

169 stored in a laboratory free of volatile organics. For analysis of chlorophyll $a$ and

170 particulate organic carbon/nitrogen, 600 to $1000 \mathrm{~mL}$ of sample water for each

171 sample was filtered onto a $25 \mathrm{~mm} \mathrm{GF} / \mathrm{F}$ filter, folded in half, wrapped in Al foil and

172 frozen to $-20^{\circ} \mathrm{C}$. For flow cytometry (FCM), $1.5 \mathrm{~mL}$ of unfiltered water was fixed at

$1730.5 \%$ paraformaldehyde (amended with $100 \mu \mathrm{L} 8 \%$ ampulated paraformaldehyde,

174 Electron Microscopy Sciences, Hatfield, PA, USA) in a $2 \mathrm{~mL}$ polypropylene cryovial,

175 mixed briefly and then frozen to $-80^{\circ} \mathrm{C}$. All samples were immediately refrigerated

176 in the field and frozen or refrigerated within 6 hours of collection for long-term

177 storage.

178

179 Inorganic nutrient and organic matter concentration measurements

180 Nutrient samples were thawed to room temperature, mixed thoroughly and

181 analyzed on a Seal Analytical Segmented Flow Injection AutoAnalyzer AA3HR for

182 simultaneous determination of soluble reactive phosphate $\left(\mathrm{PO}_{4}^{3-}\right)$, ammonium

$183\left(\mathrm{NH}_{4}{ }^{+}\right)$, nitrate+nitrite $\left(\mathrm{N}+\mathrm{N} ; \mathrm{NO}_{3}{ }^{-}+\mathrm{NO}_{2}-\right)$, silicate $\left(\mathrm{SiO}_{4}\right)$ and total dissolved

184 nitrogen and phosphorus (TDN, TDP; via in-line persulfate/UV oxidation). DOC and 
185 TDN samples (GF/F filtrate frozen in glass vials) were measured as non-purgeable

186 organic carbon and nitrogen via acidification, sparging and high-temperature

187 catalytic oxidation on a Shimadzu TOC-L with TMN-L attachment, ensuring that

188 Deep Seawater Reference waters from the University of Miami Consensus Reference

189 Materials Project measured within specifications in each run to facilitate

190 comparison of results to those obtained by the international DOM community.

191 Chlorophyll $a$ (Chla) concentrations were measured by acetone extraction and

192 fluorescence spectroscopy on a modified Turner 10-AU fluorometer following

193 Welschmeyer (1994). Particulate organic carbon (POC) and nitrogen (PON)

194 concentrations were determined via filter combustion on an Exeter Analytical CE

195440 Elemental Analyzer after acid fumigation to remove particulate inorganic

196 carbon, drying, weighing and packing into tin capsules. TA samples were analyzed

197 using open cell potentiometric titrations on a 166 Mettler T50 autotitrator and

198 calibrated against a Certified Reference Material (Dickson et al., 2007). Salinity was

199 measured as electrical conductivity with a combination platinum ring electrode -

200 thermistor (Metrohm 6.0451.100) on a Metrohm conductivity module using Tiamo

201 software (v2.4). All solute and particulate samples were analyzed in the SOEST

202 Analytical Laboratory (http://www.soest.hawaii.edu/S-LAB/).

204 To assess field and technical replicability, a separate nutrient sample was collected

205 in situ at a subset of 15 locations and filtered immediately through a

206 polyethersulfone $0.45 \mu \mathrm{m}$ groundwater cartridge filter (AquaPrep 600, Pall Life

207 Sciences, Ann Arbor, MI, USA). Samples were stored refrigerated in $250 \mathrm{~mL}$

208 polyethylene bottles for 1 month and analyzed for salinity and by flow injection

209 autoanalyzer in parallel with the primary samples. The replicated samples were

210 representative of the range of biogeochemical zones, spanning $75 \%$ of the

211 lognormal data range for each parameter. Linear models of $\log _{10}$-transformed data

212 collected by the two methods demonstrated strong congruency. The two methods

213 were highly correlated $\left(\mathrm{r}>0.98\right.$ for TDN, TDP, $\mathrm{PO}_{4}{ }^{3-}, \mathrm{N}+\mathrm{N}, \mathrm{SiO}_{4}$, Salinity and $\mathrm{r}=0.85$

214 for $\mathrm{NH}_{4}+$ ). In addition, both least-squares and orthogonal (Model II or reduced major 
215 axis) regression model slopes for all 7 parameters $(\mathrm{p}<0.001)$ were not significantly

216 different from 1 (95\% confidence intervals bracketed 1 ). Intercepts were nearly all

217 non-significant (intercept $\mathrm{p}>0.25$, except TDP $\mathrm{p}=0.0027$ ), indicating no offset

218 between the two sample sets; when intercepts were constrained to zero, slopes

219 remained not significantly different from 1 . This analysis indicates that

220 measurements of standard solutes were robust to minor variation in sample

221 collection and storage as well as field variation in sampling; the primary samples

222 were used in all subsequent analyses.

224 Dissolved organic N and P (DON, DOP) were calculated as the difference between

225 TDN, TDP and inorganic species of $\mathrm{N}$ and P: DOP $=$ TDP $-\mathrm{PO}_{4}{ }^{3-}$ and DON $=$ TDN -

$226 \mathrm{~N}+\mathrm{N}-\mathrm{NH}_{4}+$. TDN was measured using two separate methods: via high temperature

227 catalytic oxidation (HTCO) and subsequent ozonation chemiluminescence of $0.7 \mu \mathrm{m}$

228 filtrate (GF/F) on a Shimadzu TMN-L and via persulfate alkaline oxidation and 229 subsequent colorimetric cadmium reduction of $0.2 \mu \mathrm{m}$ filtrate (Sterivex) on a Seal

230 Analytical AA3HR (described above). The two methods yielded highly correlated

231 measures of TDN $(r=0.97, n=46)$ but the HTCO method yielded consistently lower

232 estimates of TDN (Model II lognormal regression slope of 0.85 with $95 \%$ confidence

233 interval of 0.79 to 0.91 ). Estimates of DON derived from the two TDN measurements

234 did not covary and were not significantly related to $\mathrm{N}+\mathrm{N}$ or DOC ( $>0.05)$. When

$235 \mathrm{~N}+\mathrm{N}$ concentrations exceeded $40 \mu \mathrm{mol} \mathrm{L}^{-1}$ estimates of DON from HTCO were

236 negative; for all subsequent analyses, Seal autoanalyzer TDN measurements were

237 used to maintain methodological consistency with other $\mathrm{N}$ and P measures.

239 Radon activity measurements

240 Coastal radon activities were measured using a RAD AQUA closed air loop

241 continuous equilibrium exchanger accessory for the RAD7 radon detector

242 (Durridge Inc., Billerica, MA). The system was mounted on a small boat hand-pulled

243 along the shoreline and in perpendicular transects. The system was mounted on a

244 small boat and hand-pulled along pre-determined GPS transects. Coastal springs and 
245 diffuse seepage was identified by moving along the shoreline and shore-

246 perpendicular transects were used to determine the extent of significant

247 groundwater plumes at the two focus areas. The air-water exchanger of the RAD-

248 AQUA was fed by water using a submersible bilge pump submersed $0.2 \mathrm{~m}$ below the

249 water surface. The instrument recorded radon in 5-minute integrated intervals

250 providing a spatial resolution of 50-100 meters. Radon in air values were converted

251 to radon in water activities using temperature and salinity recorded by a YSI (V2-2)

252 multiparameter probe (Schubert et al., 2012). It has been shown previously that the

253 nearshore water residence time at the sampling sites is one tidal cycle so the

254 reported radon values are not corrected for radon decay and evasion to the

255 atmosphere (Holleman, 2011). The radon survey covered the whole bay area but

256 only results relevant to Black Point and Wailupe are included in this analysis.

\section{Flow cytometry}

259 Flow cytometry was used to measure both autofluorescent and total nucleic-acid

260 stained cell concentrations in fixed unfiltered water samples (Nelson et al., 2011).

261 Samples were thawed and placed in $250 \mu \mathrm{L}$ aliquots in 96-well autosampler plates

262 in duplicate; one of the two wells was mixed with SYBR Green I stain (1X final

263 concentration) within $2.5 \mathrm{~h}$ of analysis. Samples were analyzed on an Attune

264 Acoustic Focusing Cytometer with Autosampler Attachment (Life Technologies,

265 Eugene, OR, USA). Samples were run at flow speeds of $100 \mu \mathrm{L} \mathrm{min}^{-1}$ on standard

266 sensitivity; $150 \mu \mathrm{L}$ of sample was aspirated, $75 \mu \mathrm{L}$ was counted and data was

267 collected only from the last $50 \mu \mathrm{L}$ (event rates were empirically determined to be

268 steady only after $25 \mu \mathrm{L}$ of continuous sample injection). For SYBR-stained cells a

269 blue laser ( $488 \mathrm{~nm}$, threshold $10,000 \mathrm{rfu}$, voltage $2300 \mathrm{mV}$ ) was used to excite the

270 dye and cell counts obtained by increasing the voltage to maintain event counts of

271 blank controls (SYBR-stained $0.2 \mu \mathrm{m}$ filtered DIW) below 100 events s$^{-1}$ and event

272 counts of environmental samples below 1500 events s-1 ${ }^{-1}$. This allowed for clear

273 gating of plankton cells as populations distinct from instrument noise in bivariate

274 plots of sidescatter and green fluorescence (530/30 $\mathrm{nm}$ bandpass fluorescence; BL1 
275 channel). For autofluorescent cells a combination threshold on Violet ( $405 \mathrm{~nm}$ ) OR

276 Blue (488 $\mathrm{nm}$ ) laser excitation and red emission (600 $\mathrm{nm}$ and $640 \mathrm{~nm}$ longpass

277 filters, respectively VL3 and BL3 channels, $1000 \mathrm{rfu}, 2500 \mathrm{mV}$ ) was used, and size-

278 based sidescatter gating was applied to differentiate autofluorescent photosynthetic

279 bacterioplankton (PBact) from photosynthetic autofluorescent picoeukaryotes

280 (PEuks). Concentrations were corrected for stain and paraformaldehyde dilution

281 factors, and heterotrophic bacterioplankton counts (HBact) were calculated as the

282 difference of SYBR and total autofluorescent counts. These settings were empirically

283 tested for streamwater, coastal and open ocean heterotrophic and autofluorescent

284 bacterioplankton from the North Pacific Subtropical Gyre down to depths of $4000 \mathrm{~m}$

285 with densities ranging from 100 to 2000 cells $\mu \mathrm{L}^{-1}$ for SYBR-stained cells and 1 to

286500 cells $\mu \mathrm{L}^{-1}$ for autofluorescent cells; counts matched those derived from

287 epifluorescent microscopy within $10 \%$ in all cases.

Fluorescent dissolved organic matter (fDOM) measurement

290 Analysis of fDOM was conducted on a Horiba Aqualog scanning fluorometer with

291 150W Xe excitation lamp, Peltier-cooled CCD emission detector and simultaneous

292 absorbance spectrometer. Samples were warmed to room temperature $\left(22^{\circ} \mathrm{C}\right)$ for 2

293 hours while the Xe bulb warmed. Excitation-emission matrices (EEMs) were

294 measured from each of 48 samples in a $1 \mathrm{~cm}$ DIW-leached and rinsed quartz cuvette

295 (3-Q-10, Starna Cells, Atascadero, CA, USA) with 4 DIW blanks run at the start and

296 end of the contiguous $3 \mathrm{~h}$ analysis period. Water was excited through a $5 \mathrm{~nm}$

297 bandpass subtractive double monochromator in declining $5 \mathrm{~nm}$ sequence intervals

298 from 500 to $240 \mathrm{~nm}$ and emission was integrated $4 \mathrm{~s}$ at each step and binned in 4.65

$299 \mathrm{~nm}$ intervals (8-pixel bins) from 250 to $800 \mathrm{~nm}$. Scans were processed using custom

300 scripts in Matlab (v2007b) as follows: 1) first inner filter effect correction was

301 applied to account for the quenching of fluorescence by absorbance following the

302 recommendations of Kothawala, et al. (2013) by multiplying by the antilog of the

303 average of absorbances at the wavelengths of excitation and emission for each

304 fluorescence data point, 2) next EEMs were scaled to Raman units (RU) by dividing 
305 by the integrated emission range of 381 to $426 \mathrm{~nm}$ at an excitation of $350 \mathrm{~nm}$ in

306 averaged DIW blanks (Lawaetz and Stedmon, 2009; Murphy et al., 2010) and 3)

307 average DIW blank EEMs were subtracted from each sample.

309 fDOM modelling and indices

310 We used Parallel Factor Analysis (PARAFAC) to derive four modelled fDOM

311 components with the DOMFluor toolbox (v1.7; Stedmon and Bro, 2008), trimming

312 Rayleigh and Raman scatter, testing for outliers (none were identified), deriving up

313 to 6 PARAFAC components then using split-half validation and random initialization

314 to determine the appropriate number of modeled components (in this case only the

315 first 4 could be validated). We also calculated a suite of derived indices from each

316 EEM that are commonly used to differentiate aspects of fDOM character and help

317 interpret DOM sources. The ratio of marine-derived to terrigenous fDOM (e.g. M:C)

318 was calculated as the ratio of fluorescence at Ex310/Em410 divided by fluorescence

319 at Ex345/Em445 (Burdige et al., 2004). The M:C has had utility in differentiating

320 between marine- and terrestrial-derived fDOM (Burdige et al., 2004; Helms et al.,

321 2013). The Fluorescence index (FI; McKnight et al., 2001), calculated as the ratio of

322 fluorescence at $470 \mathrm{~nm}$ to $520 \mathrm{~nm}$ under $370 \mathrm{~nm}$ excitation (Cory et al., 2010; Maie

323 et al., 2006), expresses the ratio of terrigenous vs. autochthonous-produced humic

324 DOM. Similarly, the fluorescent biological index (BIX), which is associated with

325 microbially-derived and autochthonous DOM, was calculated as the ratio of

326 fluorescence at $380 \mathrm{~nm}$ to $430 \mathrm{~nm}$ under $308 \mathrm{~nm}$ excitation (Huguet et al., 2009).

327 BIX $>1$ can indicate a strong signal of recent autochthonous DOM production,

328 whereas those $<0.7$ reflect older authochthonous DOM (Huguet et al., 2009). Lastly,

329 the fluorescent humification index (HIX), often used to estimate the extent of DOM

330 diagenesis or maturation in soils, was calculated as the integrated fluorescence from

331434 to $480 \mathrm{~nm}$ divided by the integrated fluorescence from 300 to $346 \mathrm{~nm}$ under

332 254nm excitation (Zsolnay et al., 1999). High HIX values ( $>10)$ indicate aromatic

333 DOM (potentially from terrestrial or marine humic acids) whereas low values $(<4)$

334 reflect more autochthonous origin (Birdwell and Engel, 2010). Lastly, we used the 
335 absorbance spectra to calculate specific ultraviolet absorbance $\left(\mathrm{SUVA}_{254}\right)$ by

336 dividing the linear absorbance $\left(\mathrm{m}^{-1}\right)$ by DOC $\left(\mathrm{mg} \mathrm{L}^{-1}\right)$ (Weishaar et al., 2003).

\section{Statistical analyses}

339 All nutrient, organic, carbonate, fDOM indices and flow cytometry parameters were

$340 \log _{10}$-transformed to better approximate a gaussian (normal) distribution before

341 statistical analysis; raw fDOM values were normally distributed and were not

342 transformed for statistical analysis. Hierarchical clustering (Ward's minimum

343 variance method) was used to group samples according to similarity in multiple

344 biogeochemical parameters as a way to define clusters of samples with similar

345 properties. Each parameter was first standardized (by subtracting the column mean

346 and dividing by the column standard deviation) to avoid weighting clusters by

347 absolute measurement values. To conservatively define groups of samples

348 according to relative proportion of SGD influence based on inorganic chemical

349 composition, samples were initially clustered by the full suite of 7 standard

350 inorganic solute measurements made $\left(\mathrm{PO}_{4}{ }^{3-}, \mathrm{N}+\mathrm{N}, \mathrm{NH}_{4}{ }^{+}, \mathrm{SiO}_{4}\right.$, Salinity, $\mathrm{TA}$ and $\left.\mathrm{Rn}\right)$.

351 This clustering approach differentiated samples into spatially-distributed

352 "biogeochemical provinces" interpreted as SGD Springs, Transition SGD mixing

353 Zones, Diffuse SGD Zones and Ambient Reef waters (detailed further in results).

354 Analysis of variance (ANOVA) was then used to test if mean values of organic

355 parameters differed among the inorganic biogeochemical provinces and sites, with

356 Tukey and Dunnet's post hoc tests used to assess pairwise differences among groups

357 at $\alpha=0.05$. Chi-square tests were used to assess similarity in cluster assignment of

358 samples using different suites of organic variables. Pearson correlation and linear

359 regression models (least squares and orthogonal/reduced major axis/Model II

360 approaches) were used to assess covariance among variables.

\section{Results:}

364 Distributions of dissolved inorganic solutes and delineation of groundwater influence 
365 At each site SGD sources and dispersal patterns were clearly visualized by contour 366 mapping of conservative inorganic solute tracer concentrations in surface samples 367 at low tide (Figure 2a-f). Concentration gradients were consistent with rapid 368 dilution within $200 \mathrm{~m}$ of the source springs at each site. Contours of the fDOM 369 humification index (HIX) closely tracked these conservative solute gradients across 370 the reef platform (Figure 2g,h), and HIX was highly correlated with salinity and 371 silicate consistently at both sites ( $r>0.75$; Figure S2), demonstrating that fDOM 372 parameters tracked salinity.

374 Hierarchical clustering of samples according to the suite of 7 standard inorganic 375 solute measurements $\left(\mathrm{SiO}_{4}\right.$, Salinity, $\mathrm{Rn}, \mathrm{PO}_{4}{ }^{3-}, \mathrm{N}+\mathrm{N}, \mathrm{NH}_{4}{ }^{+}$and $\left.\mathrm{TA}\right)$ separated 376 samples into six distinct groups, which we refer to subsequently as "biogeochemical 377 provinces" because of their spatial differentiation (Figure 3a). Groundwater springs 378 at Wailupe and Black Point were distinct (BP Spring and WL Spring Provinces), 379 areas of significant SGD mixing at Wailupe and Black Point were distinct (BP 380 Transition Zone and WL Transition Zone Provinces), while Diffuse SGD Zones and

381 Ambient Reef provinces did not differ between sites (Figure 3b,c). Figure 3d,e 382 provides a conceptual spatial schematic of the biogeochemical provinces defined in 383 Figure 3a that are referenced throughout this study (e.g. Spring, Transition Zone, 384 Diffuse Zone and Ambient Reef).

386 At the Springs, silicate concentrations were $>500 \mu \mathrm{mol} \mathrm{L}^{-1}$, salinities $<10$ and radon 387 activities $>150 \mathrm{dpm} \mathrm{L}^{-1}$ while Ambient Reef waters had silicate concentrations $<5$ $388 \mu \mathrm{mol} \mathrm{L}^{-1}$, salinities near 30 and radon activities $<20 \mathrm{dpm} \mathrm{L}^{-1}$; Transition and Diffuse 389 Zones exhibited characteristic intermediate silicate concentrations and did not 390 differ significantly from Ambient Reef sources in salinity or radon (Table 1, Figure 391 S3). Sites did not differ significantly in any of the inorganic tracer solutes except that 392 Transition Zone waters had more radon at Black Point (mean $148 \mathrm{dpm} \mathrm{L}^{-1}$ ) than at 393 Wailupe (mean $43 \mathrm{dpm} \mathrm{L}^{-1}$; Figure S3). Springs at both sites were significantly 394 higher in $\mathrm{N}+\mathrm{N}\left(>50 \mu \mathrm{mol} \mathrm{L}^{-1}\right)$ and $\mathrm{PO}_{4}{ }^{3-}\left(>1.5 \mu \mathrm{mol} \mathrm{L}^{-1}\right)$ than any other samples; 
395 nearby Transition Zone samples remained significantly higher ( $>5 X)$ than adjacent 396 Diffuse Zone and Ambient Reef waters that did not differ significantly from each 397 other ( $<1.5 \mu \mathrm{mol} \mathrm{L}^{-1} \mathrm{~N}+\mathrm{N}$ and $<0.15 \mu \mathrm{mol} \mathrm{L}^{-1} \mathrm{PO}_{4}{ }^{3} ;$; Figure S4). In contrast, $\mathrm{NH}_{4}{ }^{+}$ 398 concentrations were depleted in Springs (near limits of detection) relative to the 399 adjacent Transition Zone and Diffuse Zone waters, both of which were strikingly 400 enriched in $\mathrm{NH}_{4}{ }^{+}$(mean $0.9 \mu \mathrm{mol} \mathrm{L}^{-1}$ ) above Ambient Reef samples (mean $0.3 \mu \mathrm{mol}$ $401 \mathrm{~L}^{-1}$; Table 1 and Figure S4). TA in the groundwater Springs differed markedly 402 between the two sites, being significantly elevated at Black Point (mean $2826 \mu \mathrm{mol}$ $403 \mathrm{~kg}^{-1}$ ) and significantly depleted at Wailupe (mean $1616 \mu \mathrm{mol} \mathrm{kg}^{-1}$ ) relative to all 404 other biogeochemical provinces at both sites (which did not differ significantly; 405 mean concentrations $2250 \mu \mathrm{mol} \mathrm{kg}{ }^{-1}$; Table 1 and Figure S4).

407 Distributions of particulate and dissolved organics:

408 Hierarchical clustering of samples according to a suite of 9 measured dissolved and 409 particulate organic matter concentrations and ratios (Chl $a$, Picoeukaryotic 410 phytoplankton, autotrophic bacterioplankton, heterotrophic bacterioplankton, DOC, 411 DON, DOP, DOC:N and TN:TP) yielded 6 distinct groups (Figure 4a) with spatial 412 distributions of sample types consistent with SGD gradients (Figure 4b,c). Group 413 assignment of samples by clustering on inorganic solutes (Fig. 3a) and organic 414 matter (Fig. 4a) was highly congruent (Contingency $\mathrm{R}^{2}=0.63$, Pearson Chi-square 4150.96 and $p<0.0001$ for Low Tide samples), with $75 \%$ of the samples assigned to 416 identical groups (Figure 4a). Spring samples were all assigned perfectly, but Black 417 Point samples were more homogenous spatially in terms of organic matter than 418 observed with inorganic solutes and did not separate clearly among Transition 419 Zone, Diffuse Zone and Ambient Reef types, potentially indicating a more extensive 420 influence of SGD on the reef organic field (Figure $4 \mathrm{~b}$ ). Wailupe spatial patterning of 421 organic matter was consistent with inorganic solutes (Figure 4c).

423 DOC was significantly depleted in both Springs relative to the surrounding waters 424 (mean $85 \mu \mathrm{mol} \mathrm{L}^{-1}$ ); concentrations in Wailupe Springs (mean $20 \mu \mathrm{mol} \mathrm{L}-1$ ) were 
425 more than twice as low as those in Black Point Springs (mean $47 \mu \mathrm{mol} \mathrm{L}^{-1}$; Table 1

426 and Figure S5). The two Springs had very different DON concentrations, both

427 significantly different from the surrounding waters (mean $6.5 \mu \mathrm{mol} \mathrm{L}^{-1}$ ), with Black

428 Point highly enriched (mean $34 \mu \mathrm{mol} \mathrm{L}^{-1}$ ) and Wailupe significantly depleted (mean

$4291.4 \mu \mathrm{mol} \mathrm{L}^{-1}$ ). Dissolved organic phosphorus was unresolvable in Springs and near

430 detection limits in Transition Zone regions, and did not differ among Diffuse Zones

431 and Ambient Reef waters (mean $0.3 \mu \mathrm{mol} \mathrm{L}^{-1}$ ). Particulate organic concentrations

432 (POC, PON and chl $a$; Fig. S6) and flow cytometry (Picoeukaryotic phytoplankton,

433 Autotrophic and Heterotrophic bacterioplankton; Fig S7) pairwise differences

434 among biogeochemical provinces were mostly non-significant due to high variance,

435 but overall exhibited trends of particulate depletion in Springs and plankton

436 enrichment in the surrounding Transition Zone waters (Figs. S6, S7).

438 fDOM characteristics and distributions:

439 The PARAFAC modelling validated 4 fluorescence components that covaried with

440 fluorescence regions widely identified from marine systems (Regions: A - humic-like

441 UV excitation; M - visible, blue-shifted, marine humic-like; C - visible excitation,

442 humic-like; and T - aromatic amino protein-like; Coble 1996) both in terms of

443 spectral characteristics (Fig. S8) and in terms of standardized distributions among

444 variables within this dataset (Figure S8e). In addition, the spectral loadings of our

445 PARAFAC components (Fig. S8a-d) matched PARAFAC components found in marine

446 systems in various recent reviews: Component $1\left(\operatorname{Em}\left(2^{\circ}\right) / \mathrm{Ex}: 260(375) \mathrm{nm} / 375\right.$

$447 \mathrm{~nm}$ ) is consistent with component C1 from Jørgensen et al. (2011) and component

448 C2 from Ishii and Boyer (2012). Our Component $2\left(\operatorname{Em}\left(2^{\circ}\right) / E x:<250(325) \mathrm{nm} /\right.$

$449400-480 \mathrm{~nm}$ ) corresponds to component C4 from Jørgensen et al. (2011) and

450 component $\mathrm{C} 3$ from Ishii and Boyer (2012). Component $3\left(\operatorname{Em} / \operatorname{Ex}\left(2^{\circ}\right): 300\right.$ -

$451380 \mathrm{~nm} / 510(480 \mathrm{~nm})$ corresponds to component C4 in Kowalczuk et al. (2009).

452 Component $4\left(\mathrm{Ex} / \mathrm{Em}\left(2^{\circ}\right): 260 \mathrm{~nm} / 330(510 \mathrm{~nm})\right.$ corresponds to component $\mathrm{C} 2$ in

453 Jørgensen et al. (2011). 
455 Each of the four PARAFAC components differed significantly among the

456 biogeochemical provinces (ANOVA $\mathrm{p}<0.0001$ ). At Black Point both Spring and

457 Transition Zone provinces were enriched relative to Diffuse Zone and Ambient Reef

458 waters for all components, indicating that total fDOM was elevated in the

459 groundwater. In contrast, Wailupe Transition and Diffuse Zones were enriched

460 relative to both Spring and Ambient Reef waters (Fig. 5), consistent with the idea of

461 production of fDOM in the SGD-influenced reef waters of Wailupe. Notably, at Black

462 Point, although fDOM decreased from Spring to Ambient Reef waters, DOC exhibited

463 some enrichment in the transition and diffuse zones, suggesting that autochthonous

464 production of non-fluorescent DOM may have occurred in the diffuse zones.

465 Within any of the four biogeochemical provinces there were clear site differences in

466 fDOM quantity: Black Point Spring samples were enriched in all four components

467 relative to Wailupe Springs while the reverse was true in Diffuse Zone samples, with

468 Wailupe enriched for components A, M and C (Fig. 5), again consistent with the idea

469 of production of fDOM in the SGD-influenced reef waters of Wailupe.

471 The four ratio-based fDOM indices exhibited very different patterns within sites,

472 emphasizing that each index is assessing a different aspect of the character of FDOM

473 (Figure 6). In SGD Springs, the humification index, HIX, was more than double ( $>7$ )

474 Ambient Reef values $(<3)$ at both sites (Table 1 ). HIX was highly correlated with

475 salinity and silicate consistently between sites ( $r>0.75$; Figure $S 2)$ and declined

476 continuously with distance from the Springs (Figure 2). The M:C index covaried with

477 HIX ( $r=0.83)$ and was also significantly enriched in Springs and in Transition Zone

478 waters relative to the Diffuse Zone and Ambient Reef waters. Relative to ambient

479 waters, the Wailupe Spring had a significantly higher fluorescence index (FI) and

480 SUVA 254 was significantly greater in the Black Point Spring. BIX ranged from 0.76-

4810.86 across both sites, and was generally elevated in Black Point relative to Wailupe,

482 but did not differ significantly among water types. Indices did not differ between

483 sites within a given biogeochemical province (Figure 6). 
485 Hierarchical clustering of samples according to a suite of 9 fDOM-derived 486 parameters (4 PARAFAC components, 4 fDOM indices and SUVA $_{254}$ ) separated 487 samples into 6 groups (Figure 7a) with spatial distributions of sample types 488 consistent with SGD gradients (Figure 7b,c). Group assignment of samples by fDOM 489 characteristics was generally congruent with clustering by inorganic solutes (Fig. 3) 490 and organic matter (Fig. 7; Contingency $R^{2}=0.52$ and 0.50, respectively, Pearson 491 Chi-square 93 and 78, respectively and $\mathrm{p}<0.0001$ for Low Tide samples), with 70\% 492 of the samples assigned to identical groups. As with the organic matter clustering, 493 Spring samples were all assigned perfectly, but at both sites the other

494 biogeochemical provinces were less clearly differentiated spatially in terms of fDOM 495 than observed with inorganic solutes. Notably, both Transition Zone and Diffuse 496 Zone samples appeared to be different in fDOM parameters between Wailupe and 497 Black Point (Figure 7a), potentially indicating a more extensive influence of SGD on 498 the reef fDOM field. The two SGD springs (and the two diffuse zones) may be 499 differentiated according to their fDOM amount (i.e. fluorescence intensities of 500 fluorophores) (Fig. 5) but cannot be clearly discriminated by fluorophore ratio 501 indices (Fig. 6).

502

\section{Discussion}

504

505 Biogeochemical characteristics of groundwater entering Maunalua Bay

506 Groundwater discharging from springs in Maunalua Bay showed some consistencies

507 and differences between the Black Point and Wailupe sites. Both sites released

508 groundwater with biogeochemical profiles consistent with previous studies of SGD

509 in coral reefs (Swarzenski et al., 2013), including low salinities and elevated

510 concentrations of radon and silicate, elevated $\mathrm{PO}_{4}{ }^{3-}$ and $\mathrm{N}+\mathrm{N}$, depleted $\mathrm{NH}_{4}{ }^{+}$

511 concentrations and depleted DOC, POC, chl $a$ and phytoplankton cells (Table 1, Figs.

$512 \quad 2-4$ and S3-S7). However, some measurements were strongly and significantly

513 different between the two Springs. First, the Wailupe Springs were significantly

514 depleted in TA and DON relative to the adjacent waters whereas the Black Point TA

515 and DON were significantly greater than the adjacent waters, suggesting a 
516 fundamentally different hydrological origin (Figs. S4, S5). Second, while both

517 Springs were depleted in DOC relative to the adjacent waters, the Wailupe site had

518 nearly half the DOC concentrations of the Black Point site (Fig. S5), yet Black Point

519 Springs were strongly depleted in bacterioplankton, nearly 4 times less than

520 Wailupe Springs or the surrounding ocean (Fig. S7). Aside from the unexpectedly

521 high concentrations of bacterioplankton in the Wailupe Springs, these patterns

522 suggest that groundwater flowpaths at these two sites are very different, potentially

523 capturing differences in land-use and geology in these two parts of the watershed.

524 Black Point has a higher density of on-site sewage disposal (septic and cesspool)

525 systems (Whittier and El-Kadi, 2009), but we do not have evidence that the high

526 nutrient or fDOM levels are due to these potential sources. The difference in radon

527 concentrations between the springs (Table 1) suggest that groundwater at Black

528 Point flows through rocks generating more radon (i.e., more enriched in $\mathrm{U}$ and $\mathrm{Ra}$ )

529 than the rocks and sediments at Wailupe, indicating differences in the geologic

530 make-up of the aquifer. Land-use, including density of septic systems, presence of

531 historic agricultural sites, etc. is a likely cause for differences in nutrient and organic

532 matter levels.

533

534 fDOM characteristics of groundwater entering Maunalua Bay

535 Across sites, SGD was significantly enriched in aromatic/humic components (e.g.,

536 Regions A and M, HIX, M:C) and had higher specific ultraviolet absorbance (Table 1).

537 The Black Point Springs had significantly more of all 4 fDOM components than the

538 Wailupe Springs and were enriched in all components relative to the Ambient Reef

539 waters (Fig. 5); the Wailupe Springs had fDOM quantities identical to Ambient Reef

540 waters for all four components. The lack of significant differences in fDOM indices

541 between these two sites within any given biogeochemical province (Fig. 6) suggests

542 that SGD fDOM molecular composition was similar. However, groundwater DOC

543 concentrations overall were significantly lower than the overlying reef, and when

544 combined with elevated fDOM (at least at Black Point) and significantly higher ratios

545 of humic compounds (HIX Index, Figs 2 and 6) our data indicate that a greater

546 proportion of the DOC in the groundwater is fluorescent. Indeed, ratios between any 
547 of the four PARAFAC components and DOC concentrations, a proxy for specific

548 fDOM fluorescence, were significantly enriched in both Springs relative to the

549 adjacent waters (ANOVA with Tukey post hoc $\mathrm{p}<0.0001$ ), indicating that

550 groundwater DOC has a much higher fluorescence than marine DOC. Although both

551 overall fDOM and DOC concentrations were significantly higher in the Black Point

552 site (Figs 5 and S5), ratios of fDOM components to DOC did not differ between sites,

553 only between biogeochemical provinces, again emphasizing that the DOC in SGD is

554 consistently highly fluorescent with a strong humic component (Figs 2, 6, S2).

556 Dispersal and biogeochemical influence of submarine groundwater discharge

557 In an observational study it is difficult to separate cause from effect, and in the case

558 of the current dataset we cannot definitively determine whether parameters that

559 differ significantly in the Transition and Diffuse Zones from the Ambient Reef waters

560 are driven by dilution of SGD or stimulation of biogeochemical processes that

561 subsequently alter the characteristics of the water. However, the vast majority of the

562 measured parameters exhibited statistically robust gradients spatially concordant

563 with SGD dispersal across the reef. A handful of parameters did not follow this

564 trend, and it is likely that these represent reef-specific production or consumption

565 processes. Ammonium was the only inorganic solute that exhibited enrichment in

566 the Transition Zone and Diffuse Zone provinces above both Spring and Ambient

567 Reef endmembers, suggesting a production process (Figure S4). Moreover, this

568 parameter was only significantly enriched in the Transition Zone province, not in

569 the adjacent Reef waters, possibly indicating rapid consumption and

570 ammonification of DON, dissimilatory reduction of nitrate to ammonia (DNRA), or

571 recycling of nitrate to ammonia through organic assimilation and remineralization.

572 A similar pattern was observed in particulate organic matter, with the Wailupe site

573 exhibiting enriched $\mathrm{Chl} a$ and eukaryotic phytoplankton counts suggestive of some

574 stimulation of water column productivity by the groundwater nutrient delivery.

575 Finally, there was consistent enrichment of fDOM components A,C and T in the

576 Transition Zone and Diffuse Zone provinces above levels found in the Springs and

577 Ambient Reef zones (Fig. 5). Region $\mathrm{C}$ has been associated with microbial 
578 production processes in marine systems and Region $\mathrm{T}$ is generally associated with

579 proteinaceous material because of the similarities to pure tryptophan fluorescence

580 (Coble et al., 2014). One interpretation of these patterns is that these components

581 represent fDOM being produced by the reef habitat; whether that production is

582 influenced directly or indirectly by SGD inputs or is simply a characteristic of reefs

583 generally is not currently known. Certainly there are potential physicochemical

584 changes in DOM across these gradients due to photodegradation, metal-ligand

585 bonding, $\mathrm{pH}$, and salinity shifts that impart changes to fDOM character (Helms et al.,

586 2013; Osburn et al., 2013).

587

588 Recommendations for the use of fDOM to track groundwater discharge in reefs

589 This study shows clearly how fDOM spectral analyses can be used to differentiate

590 water masses according to the degree of influence of SGD in two sites with very

591 different SGD organic matter profiles, consistent with previous work conducted in

592 coral reef environments with allochthonous DOM inputs (Tedetti et al., 2011). Based

593 on our observations, it is clear that groundwater entering Maunalua Bay contains a

594 significant quantity of fDOM with more than double the humification index (HIX) of

595 the receiving Diffuse Zone and Ambient Reef waters (Figure 6, Table 1), consistent

596 with fDOM from sedimentary and volcanic sources in reef ecosystems (Tedetti et al.,

597 2011). This single feature of the fDOM spectra (i.e., elevated HIX) was strongly

598 correlated with both salinity and silicate in both sites with identical slopes, and from

599 this simple index there is the potential to model these inorganic solute

600 concentrations from the HIX value (Figure S2). In addition, the groundwater sources

601 to Black Point stood out clearly from the surrounding reef in humic fluorescence

602 regions A and M (Figure 5), though not at Wailupe. These differences suggest that

603 fDOM characteristics may be able to differentiate groundwater according to land

604 use, hydrology, or other factors, allowing the development of fDOM as a

605 groundwater source-tracking tool in concert with other biogeochemical parameters.

606 Future studies should consider the use of continuous sensor monitoring of coastal

607 fDOM (our PARAFAC component C1 exhibits a secondary emission peak

608 corresponding to the excitation-emission maxima of commercial DOM sensors) and 
609 examination of the interacting roles of photobleaching and residence time in

610 defining the extent of fDOM distributions in coastal waters. Because fDOM samples

611 are relatively easy to collect (filtering a few $\mathrm{mL}$ of water into glass vials and dark

612 refrigerated storage), are unaffected by gas exchange and quick to analyze (the

613 scans took less than 5 minutes each), fDOM may prove a cost-effective and efficient

614 monitoring tool for mapping groundwater dispersal in reefs. Analyzing a sample

615 EEM spectra also provides a wealth of additional ratio-based indices and values of

616 the literature-derived identified spectral regions and our results hint that with

617 larger datasets from more reefs fDOM may be used as cost-effective monitoring tool

618 to identify new and promising indices to differentiate SGD within coastal waters.

\section{ACKNOWLEDGEMENTS}

622 The project described in this publication was supported in part by a

623 grant/cooperative agreement from the National Oceanic and Atmospheric

624 Administration, Projects R/SB-14PD (CEN), R/SB-13 (FIMT), R/SB-12 (MJD) and

625 R/SB-11 (HD) sponsored by the University of Hawai'i Sea Grant College Program,

626 School of Ocean and Earth Science and Technology, under Institutional Grant No.

627 NA140AR4170071 from the NOAA National Sea Grant Office, Department of

628 Commerce (UNIHI-SEAGRANT-JC-14-29). SJG was supported in part by Cooperative

629 Agreement Number G12AC00003 from the United States Geological Survey (USGS).

630 NJS was supported by a NOAA Dr. Nancy Foster Scholarship. CR and KL are

631 supported by the National Science Foundation Graduate Research Fellowship. This

632 is HIMB contribution 1618 and SOEST contribution TBA. The funders had no role in

633 the study design, data collection and analysis, decision to publish, or preparation of

634 the manuscript. The contents of this publication are solely the responsibility of the

635 authors and do not necessarily represent the official views of the USGS, NOAA, or

636 any of their respective subagencies. 


\section{FIGURE LEGENDS}

Figure 1. Maps of the sampling locations. Panel (a) shows the location of the two sampling sites in Maunalua Bay, O'ahu, with the inset showing the location within the Main Hawaiian Islands. Water samples were collected at each site, Black Point to the West (b) and Wailupe to the East (c), with red markers at each location where water was collected.

Figure 2. Fluorescent dissolved organic matter (fDOM) in the spatial context of Submarine Groundwater Discharge (SGD) in Maunalua Bay. Contour plots of conservative solutes and fDOM solutes at Black Point $(\mathrm{a}, \mathrm{c}, \mathrm{e}, \mathrm{g})$ and Wailupe $(\mathrm{b}, \mathrm{d}, \mathrm{f}, \mathrm{h})$ 28-29 May 2014, including salinity (a,b), silicate concentrations (c,d) $\left(\log _{10} \mu \mathrm{mol} \mathrm{L}^{-}\right.$ $\left.{ }^{1}\right)$, radon concentrations (e,f) $\left(\mathrm{dpm} \mathrm{L}^{-1}\right)$ and the fDOM humification index (g,h) (HIX). Contour gridding and interpolation was done with the kriging function (spherical semivariogram model) in ArcGIS 10.3 Spatial Analyst. All contour plots were generated from samples collected at low tide.

Figure 3. Hierarchical clustering of samples into biogeochemical provinces according to inorganic solute concentrations. Panel (a) is a hierarchical clustering dendrogram grouping samples according to similarity in $\log _{10}$ concentrations of 7 inorganic solutes (shown in heat map with legends at right; $X$ indicates no data). The tips of the dendrogram are colored to match the dendrogram clusters and define biogeochemical provinces by sets of samples with similar chemistry. WL refers to Wailupe and BP refers to Black Point. Panels (b) and (c) illustrate the spatial extent of each biogeochemical province by mapping the sample points color-coded by dendrogram clusters - defined with large colored boxes in panel (a) - at Black Point and Wailupe, respectively. Panels (d) and (e) provide a conceptual illustration of the spatial arrangement of biogeochemical provinces.

Figure 4. Hierarchical clustering of samples according to particulate and dissolved organic matter concentrations. Panel (a) is a hierarchical clustering dendrogram grouping samples (tips colored according to biogeochemical provinces delineated in Fig. 3) according to similarity in $\log 10$ concentrations of 8 organic measurements (shown in heat map with legends at right; $\mathrm{X}$ indicates no data). Panels (b) and (c) define the spatial extent of organic provinces by mapping the sample points color-coded by dendrogram clusters - defined with large colored boxes in panel (a) - at Black Point and Wailupe, respectively.

Figure 5. Comparison of fDOM PARAFAC components among the biogeochemical provinces in each reef site. Boxes depict standard interquartile ranges with medians and are labeled at top with letters for ANOVA Tukey post hoc tests; all ANOVA models $p<0.0001$ and samples with different letters are significantly different at $\alpha=0.05$.

Figure 6. Comparison of fDOM indices among the biogeochemical provinces in each reef site. Boxes depict standard interquartile ranges with medians and are 
labeled at top with letters for ANOVA Tukey post hoc tests; all ANOVA models $p<$ 0.01 and samples with different letters are significantly different at $\alpha=0.05$.

\section{Figure 7. Hierarchical clustering of samples according to fDOM spectral}

characteristics. Panel (a) is a hierarchical clustering dendrogram grouping samples (tips colored according to biogeochemical provinces delineated in Fig. 3) according to similarity in fDOM PARAFAC components and ratio-based indices (shown in heat map with legends at right; $X$ indicates no data). Panels (b) and (c) define the spatial extent of fDOM character by mapping the sample points color-coded by dendrogram clusters - defined with large colored boxes in panel (a) - at Black Point and Wailupe, respectively. 


\section{REFERENCES}

Alldredge, A., Carlson, C., Carpenter, R., 2013. Sources of Organic Carbon to Coral Reef Flats. Oceanography 26, 108-113. doi:10.5670/oceanog.2013.52

Azam, F., Fenchel, T., Field, J., Gray, J., Meyer-Reil, L., Thingstad, F., 1983. The ecological role of water-column microbes in the sea. Mar. Ecol. Prog. Ser. 10, 257-263.

Beck, A.J., Tsukamoto, Y., Tovar-Sanchez, A., Huerta-Diaz, M., Bokuniewicz, H.J., Sañudo-Wilhelmy, S.A., 2007. Importance of geochemical transformations in determining submarine groundwater discharge-derived trace metal and nutrient fluxes. Appl. Geochem. 22, 477-490. doi:10.1016/j.apgeochem.2006.10.005

Birdwell, J.E., Engel, A.S., 2010. Characterization of dissolved organic matter in cave and spring waters using UV-Vis absorbance and fluorescence spectroscopy. Org. Geochem. 41, 270-280. doi:10.1016/j.orggeochem.2009.11.002

Burdige, D.J., Kline, S.W., Chen, W., 2004. Fluorescent dissolved organic matter in marine sediment pore waters. Mar. Chem., CDOM in the Ocean: Characterization, Distribution and Transformation 89, 289-311. doi:10.1016/j.marchem.2004.02.015

Burnett, W.C., Aggarwal, P.K., Aureli, A., Bokuniewicz, H., Cable, J.E., Charette, M.A., Kontar, E., Krupa, S., Kulkarni, K.M., Loveless, A., Moore, W.S., Oberdorfer, J.A., Oliveira, J., Ozyurt, N., Povinec, P., Privitera, A.M.G., Rajar, R., Ramessur, R.T., Scholten, J., Stieglitz, T., Taniguchi, M., Turner, J.V., 2006. Quantifying submarine groundwater discharge in the coastal zone via multiple methods. Sci. Total Environ. 367, 498-543. doi:10.1016/j.scitotenv.2006.05.009

Charette, M.A., Moore, W.S., Burnett, W.C., 2008. Chapter 5 Uranium- and ThoriumSeries Nuclides as Tracers of Submarine Groundwater Discharge, in: Cochran, S.K. and J.K. (Ed.), Radioactivity in the Environment, U-Th Series Nuclides in Aquatic Systems. Elsevier, pp. 155-191.

Chen, W., Westerhoff, P., Leenheer, J.A., Booksh, K., 2003. Fluorescence Excitation-Emission Matrix Regional Integration to Quantify Spectra for Dissolved Organic Matter. Environ. Sci. Technol. 37, 5701-5710. doi:10.1021/es034354c

Coble, P.G., 1996. Characterization of marine and terrestrial DOM in seawater using excitation-emission matrix spectroscopy. Mar. Chem. 51, 325-346.

Coble, P., Lead, J., Baker, A., Reynolds, D., Spencer, R.G.M., 2014. Aquatic Organic Matter Fluorescence. Cambridge University Press.

Cory, R.M., Miller, M.P., McKnight, D.M., Guerard, J.J., Miller, P.L., 2010. Effect of instrument-specific response on the analysis of fulvic acid fluorescence spectra. Limnol. Oceanogr. Methods 8, 67-78.

Cyronak, T., Santos, I.R., Erler, D.V., Maher, D.T., Eyre, B.D., 2014. Drivers of pC02 variability in two contrasting coral reef lagoons: The influence of submarine groundwater discharge. Glob. Biogeochem. Cycles 28, 2013GB004598. doi:10.1002/2013GB004598 
Dabestani, R., Ivanov, I.N., 1999. A Compilation of Physical, Spectroscopic and Photophysical Properties of Polycyclic Aromatic Hydrocarbons. Photochem. Photobiol. 70, 10-34. doi:10.1111/j.1751-1097.1999.tb01945.x

Dailer, M.L., Knox, R.S., Smith, J.E., Napier, M., Smith, C.M., 2010. Using $\delta 15 \mathrm{~N}$ values in algal tissue to map locations and potential sources of anthropogenic nutrient inputs on the island of Maui, Hawai'i, USA. Mar. Pollut. Bull. 60, 655-671. doi:10.1016/j.marpolbul.2009.12.021

Determann, S., Lobbes, J.M., Reuter, R., Rullkötter, J., 1998. Ultraviolet fluorescence excitation and emission spectroscopy of marine algae and bacteria. Mar. Chem. 62, 137-156. doi:10.1016/S0304-4203(98)00026-7

Dickson, A.G., Sabine, C.L., Christian, J.R., others, 2007. Guide to best practices for ocean $\mathrm{CO} 2$ measurements.

Dimova, N.T., Swarzenski, P.W., Dulaiova, H., Glenn, C.R., 2012. Utilizing multichannel electrical resistivity methods to examine the dynamics of the fresh water-seawater interface in two Hawaiian groundwater systems. J. Geophys. Res. Oceans 117, C02012. doi:10.1029/2011JC007509

Dollar, S.J., Atkinson, M.J., 1992. Effects of nutrient subsidies from groundwater to nearshore marine ecosystems off the island of Hawaii. Estuar. Coast. Shelf Sci. 35, 409-424. doi:10.1016/S0272-7714(05)80036-8

Fabricius, K., 2005. Effects of terrestrial runoff on the ecology of corals and coral reefs: review and synthesis. Mar. Pollut. Bull. 50, 125-146.

Ferretto, N., Tedetti, M., Guigue, C., Mounier, S., Redon, R., Goutx, M., 2014. Identification and quantification of known polycyclic aromatic hydrocarbons and pesticides in complex mixtures using fluorescence excitation-emission matrices and parallel factor analysis. Chemosphere 107, 344-353. doi:10.1016/j.chemosphere.2013.12.087

Goñi, M.A., Gardner, I.R., 2003. Seasonal Dynamics in Dissolved Organic Carbon Concentrations in a Coastal Water-Table Aquifer at the Forest-Marsh Interface. Aquat. Geochem. 9, 209-232. doi:10.1023/B:AQUA.0000022955.82700.ed

Hansell, D.A., Carlson, C.A., 2014. Biogeochemistry of Marine Dissolved Organic Matter, Second Edition. ed. Elsevier.

Helms, J.R., Stubbins, A., Perdue, E.M., Green, N.W., Chen, H., Mopper, K., 2013. Photochemical bleaching of oceanic dissolved organic matter and its effect on absorption spectral slope and fluorescence. Mar. Chem. 155, 81-91. doi:10.1016/j.marchem.2013.05.015

Holleman, K., 2011. Comparison of submarine groundwater-derived nutrients from leeward flanks of the islands of O'ahu and Hawai'i (MS Thesis, Dept. of Geology and Geophysics). Univ. of Hawai'i at Mānoa, Honolulu, HI, USA.

Huang, W.-J., Wang, Y., Cai, W.-J., 2012. Assessment of sample storage techniques for total alkalinity and dissolved inorganic carbon in seawater. Limnol. Oceanogr. Methods 10, 711-717. doi:10.4319/lom.2012.10.711

Huguet, A., Vacher, L., Relexans, S., Saubusse, S., Froidefond, J.M., Parlanti, E., 2009. Properties of fluorescent dissolved organic matter in the Gironde Estuary. Org. Geochem. 40, 706-719. doi:10.1016/j.orggeochem.2009.03.002 
Ishii, S.K.L., Boyer, T.H., 2012. Behavior of Reoccurring PARAFAC Components in Fluorescent Dissolved Organic Matter in Natural and Engineered Systems: A Critical Review. Environ. Sci. Technol. 46, 2006-2017. doi:10.1021/es2043504

Johnson, A.G., Glenn, C.R., Burnett, W.C., Peterson, R.N., Lucey, P.G., 2008. Aerial infrared imaging reveals large nutrient-rich groundwater inputs to the ocean. Geophys. Res. Lett. 35, L15606. doi:10.1029/2008GL034574

Johnson, E.E., Wiegner, T.N., 2013. Surface Water Metabolism Potential in Groundwater-Fed Coastal Waters of Hawaii Island, USA. Estuaries Coasts 37, 712-723. doi:10.1007/s12237-013-9708-y

Jørgensen, L., Stedmon, C.A., Kragh, T., Markager, S., Middelboe, M., Søndergaard, M., 2011. Global trends in the fluorescence characteristics and distribution of marine dissolved organic matter. Mar. Chem. 126, 139-148. doi:10.1016/j.marchem.2011.05.002

Kim, G., Kim, J.-S., Hwang, D.-W., 2011. Submarine groundwater discharge from oceanic islands standing in oligotrophic oceans: Implications for global biological production and organic carbon fluxes. Limnol. Oceanogr. 56, 673682. doi:10.4319/lo.2011.56.2.0673

Kim, T.-H., Waska, H., Kwon, E., Suryaputra, I.G.N., Kim, G., 2012. Production, degradation, and flux of dissolved organic matter in the subterranean estuary of a large tidal flat. Mar. Chem. 142-144, 1-10.

doi:10.1016/j.marchem.2012.08.002

Knee, K.L., Gossett, R., Boehm, A.B., Paytan, A., 2010. Caffeine and agricultural pesticide concentrations in surface water and groundwater on the north shore of Kauai (Hawaii, USA). Mar. Pollut. Bull. 60, 1376-1382. doi:10.1016/j.marpolbul.2010.04.019

Kothawala, D.N., Murphy, K.R., Stedmon, C.A., Weyhenmeyer, G.A., Tranvik, L.J., 2013. Inner filter correction of dissolved organic matter fluorescence. Limnol. Oceanogr. Methods 11, 616-630. doi:10.4319/lom.2013.11.616

Kowalczuk, P., Durako, M.J., Young, H., Kahn, A.E., Cooper, W.J., Gonsior, M., 2009. Characterization of dissolved organic matter fluorescence in the South Atlantic Bight with use of PARAFAC model: Interannual variability. Mar. Chem. 113, 182-196. doi:10.1016/j.marchem.2009.01.015

Lapointe, B.E., 1997. Nutrient thresholds for bottom-up control of macroalgal blooms on coral reefs in Jamaica and southeast Florida. Limnol. Oceanogr. 42, 1119-1131. doi:10.4319/lo.1997.42.5_part_2.1119

Lawaetz, A.J., Stedmon, C.A., 2009. Fluorescence intensity calibration using the Raman scatter peak of water. Appl. Spectrosc. 63, 936-940.

Lee, Y.-W., Kim, G., Lim, W.-A., Hwang, D.-W., 2010. A relationship between submarine groundwater borne nutrients traced by Ra isotopes and the intensity of dinoflagellate red-tides occurring in the southern sea of Korea. Limnol. Oceanogr. 55, 1-10. doi:10.4319/lo.2010.55.1.0001

Maie, N., Parish, K.J., Watanabe, A., Knicker, H., Benner, R., Abe, T., Kaiser, K., Jaffé, R., 2006. Chemical characteristics of dissolved organic nitrogen in an oligotrophic subtropical coastal ecosystem. Geochim. Cosmochim. Acta 70, 4491-4506. doi:10.1016/j.gca.2006.06.1554 
McCook, L.J., 1999. Macroalgae, nutrients and phase shifts on coral reefs: scientific issues and management consequences for the Great Barrier Reef. Coral Reefs 18, 357-367. doi:10.1007/s003380050213

McKnight, D.M., Boyer, E.W., Westerhoff, P.K., Doran, P.T., Kulbe, T., Andersen, D.T., 2001. Spectrofluorometric characterization of dissolved organic matter for indication of precursor organic material and aromaticity. Limnol. Oceanogr. $46,38-48$.

Moore, W.S., 2010. The Effect of Submarine Groundwater Discharge on the Ocean. Annu. Rev. Mar. Sci. 2, 59-88. doi:10.1146/annurev-marine-120308-081019

Murphy, K.R., Butler, K.D., Spencer, R.G.M., Stedmon, C.A., Boehme, J.R., Aiken, G.R., 2010. Measurement of Dissolved Organic Matter Fluorescence in Aquatic Environments: An Interlaboratory Comparison. Environ. Sci. Technol. 44, 9405-9412. doi:10.1021/es102362t

Nelson, C.E., Alldredge, A.L., McCliment, E.A., Amaral-Zettler, L.A., Carlson, C.A., 2011. Depleted dissolved organic carbon and distinct bacterial communities in the water column of a rapid-flushing coral reef ecosystem. ISME J. 5, 1374-1387. doi:10.1038/ismej.2011.12

Nelson, N.B., Coble, P.G., 2009. Optical analysis of chromophoric dissolved organic matter, in: Practical Guidelines for the Analysis of Seawater. CRC Press, p. 401.

Osburn, C.L., Stedmon, C.A., Spencer, R.G.M., Stubbins, A., 2013. Linking optical and chemical properties of dissolved organic matter in natural waters. Limnol. Oceanogr. Bull. 22, 78-81.

Parsons, M.L., Walsh, W.J., Settlemier, C.J., White, D.J., Ballauer, J.M., Ayotte, P.M., Osada, K.M., Carman, B., 2008. A multivariate assessment of the coral ecosystem health of two embayments on the lee of the island of Hawai'i. Mar. Pollut. Bull. 56, 1138-1149. doi:10.1016/j.marpolbul.2008.03.004

Paytan, A., Shellenbarger, G.G., Street, J.H., Gonneea, M.E., Davis, K., Young, M.B., Moore, W.S., 2006. Submarine groundwater discharge: An important source of new inorganic nitrogen to coral reef ecosystems. Limnol. Oceanogr. 51, 343-348. doi:10.4319/lo.2006.51.1.0343

Santos, I.R., Burnett, W.C., Dittmar, T., Suryaputra, I.G.N.A., Chanton, J., 2009. Tidal pumping drives nutrient and dissolved organic matter dynamics in a Gulf of Mexico subterranean estuary. Geochim. Cosmochim. Acta 73, 1325-1339. doi:10.1016/j.gca.2008.11.029

Schubert, M., Paschke, A., Lieberman, E., Burnett, W.C., 2012. Air-Water Partitioning of 222Rn and its Dependence on Water Temperature and Salinity. Environ. Sci. Technol. 46, 3905-3911. doi:10.1021/es204680n

Smith, J.E., Hunter, C.L., Smith, C.M., 2010. The effects of top-down versus bottomup control on benthic coral reef community structure. Oecologia 163, 497507. doi:10.1007/s00442-009-1546-z

Stedmon, C.A., Bro, R., 2008. Characterizing dissolved organic matter fluorescence with parallel factor analysis: a tutorial. Limnol Ocean. Methods 6, 572-579.

Stedmon, C.A., Markager, S., 2005. Tracing the production and degradation of autochthonous fractions of dissolved organic matter by fluorescence analysis. Limnol. Oceanogr. 50, 1415-1426. 
Stimson, J., Larned, S.T., 2000. Nitrogen efflux from the sediments of a subtropical bay and the potential contribution to macroalgal nutrient requirements. J. Exp. Mar. Biol. Ecol. 252, 159-180. doi:10.1016/S0022-0981(00)00230-6

Street, J.H., Knee, K.L., Grossman, E.E., Paytan, A., 2008. Submarine groundwater discharge and nutrient addition to the coastal zone and coral reefs of leeward Hawai'i. Mar. Chem., Measurement of Radium and Actinium Isotopes in the marine environment 109, 355-376. doi:10.1016/j.marchem.2007.08.009

Swarzenski, P.W., Dulaiova, H., Dailer, M.L., Glenn, C.R., Smith, C.G., Storlazzi, C.D., 2013. A Geochemical and Geophysical Assessment of Coastal Groundwater Discharge at Select Sites in Maui and O'ahu, Hawai'i, in: Wetzelhuetter, C. (Ed.), Groundwater in the Coastal Zones of Asia-Pacific, Coastal Research Library. Springer Netherlands, pp. 27-46.

Tedetti, M., Cuet, P., Guigue, C., Goutx, M., 2011. Characterization of dissolved organic matter in a coral reef ecosystem subjected to anthropogenic pressures (La Réunion Island, Indian Ocean) using multi-dimensional fluorescence spectroscopy. Sci. Total Environ. 409, 2198-2210. doi:10.1016/j.scitotenv.2011.01.058

Weishaar, J.L., Aiken, G.R., Bergamaschi, B.A., Fram, M.S., Fujii, R., Mopper, K., 2003. Evaluation of Specific Ultraviolet Absorbance as an Indicator of the Chemical Composition and Reactivity of Dissolved Organic Carbon. Environ. Sci. Technol. 37, 4702-4708. doi:10.1021/es030360x

Welschmeyer, N.A., 1994. Fluorometric analysis of chlorophyll a in the presence of chlorophyll b and pheopigments. Limnol. Oceanogr. 39, 1985-1992. doi:10.4319/lo.1994.39.8.1985

Whittier, R.B., El-Kadi, A.I., 2009. Human and environmental risk ranking of onsite sewage disposal systems., State of Hawai'i Department of Health Safe Drinking Water Branch.

Wolanski, E., Martinez, J.A., Richmond, R.H., 2009. Quantifying the impact of watershed urbanization on a coral reef: Maunalua Bay, Hawaii. Estuar. Coast. Shelf Sci. 84, 259-268. doi:10.1016/j.ecss.2009.06.029

Zsolnay, A., Baigar, E., Jimenez, M., Steinweg, B., Saccomandi, F., 1999. Differentiating with fluorescence spectroscopy the sources of dissolved organic matter in soils subjected to drying. Chemosphere 38, 45-50. doi:10.1016/S00456535(98)00166-0 
Wailupe

\begin{tabular}{|c|c|c|c|c|}
\hline \multirow{2}{*}{\multicolumn{2}{|c|}{ Practical Salinity }} & Spring & Transition & Diffuse \\
\hline & & 4.2 & 24.4 & 30.4 \\
\hline \multicolumn{2}{|c|}{$\mathrm{SiO}_{4}(\mu \mathrm{mol} \mathrm{L}-1)$} & 6685 & 225.2 & 32.2 \\
\hline \multicolumn{2}{|c|}{$\operatorname{Rn}(\mathrm{dpm} \mathrm{L-1})$} & 160,4 & 30.4 & 23.7 \\
\hline \multicolumn{2}{|c|}{$\mathrm{N}+\mathrm{N}(\mu \mathrm{mol} \mathrm{L}-1)$} & 61.63 & 8.50 & 0.24 \\
\hline \multicolumn{2}{|c|}{$\mathrm{PO}_{4}^{3-}\left(\mu \mathrm{mol} \mathrm{L}^{-1}\right)$} & 1.89 & 0.49 & 0.05 \\
\hline \multicolumn{2}{|c|}{$\mathrm{NH}_{4}^{*}\left(\mu \mathrm{mol} \mathrm{L}^{-1}\right)$} & 0.05 & 0.89 & 0.43 \\
\hline \multicolumn{2}{|c|}{$\mathrm{TA}\left(\mu \mathrm{mol} \mathrm{kg}^{-1}\right)$} & 1614 & 2143 & 2234 \\
\hline \multicolumn{2}{|c|}{$\mathrm{DOC}(\mu \mathrm{mol} \mathrm{L}-1)$} & 200 & 70.8 & 91.4 \\
\hline \multicolumn{2}{|c|}{$\mathrm{DON}\left(\mu \mathrm{mol} \mathrm{L}^{-1}\right)$} & 1.4. & 5.0 & 6.8 \\
\hline \multicolumn{2}{|c|}{$\mathrm{Chl}$ a $\left(\mu \mathrm{g} \mathrm{L}^{-1}\right)$} & 0.06 & 0.29 & 0.12 \\
\hline \multicolumn{2}{|c|}{ HBact (cells $\mathrm{mL}^{-1}$ ) } & $4.5 \times 10^{5}$ & $2.3 \times 10^{5}$ & $5.0 \times 10^{5}$ \\
\hline \multicolumn{2}{|c|}{ PBact (cells $\mathrm{mL}^{-1}$ ) } & $1.6 \times 10^{3}$ & $7.2 \times 10^{3}$ & $1.8 \times 10^{3}$ \\
\hline \multicolumn{2}{|c|}{ PEuks (cells $\mathrm{mL}^{-1}$ ) } & $7.7 \times 10^{3}$ & $9.2 \times 10^{4}$ & $6.6 \times 10^{3}$ \\
\hline \multirow[b]{2}{*}{$\begin{array}{l}\log \text { ratio to } \\
\text { Ambient }\end{array}$} & fDOM: A & 0.028 & 0.061 & 0.056 \\
\hline & fDOM: $M$ & 0.036 & 0.073 & 0.065 \\
\hline \multirow{2}{*}{$\begin{array}{c}-1 \\
-0.6 \\
-0.2\end{array}$} & fDOM: C & 0.006 & 0.018 & 0.018 \\
\hline & fDOM: $T$ & 0.008 & 0.026 & 0.026 \\
\hline $\begin{array}{l}0.2 \\
0.8\end{array}$ & SUVA $_{254}$ & 0.95 & 0.87 & 0.82 \\
\hline 0.6 & M:C & 1.25 & 1.11 & 1.05 \\
\hline $\begin{array}{l}1.4 \\
1.8\end{array}$ & FI & 1.82 & 1.72 & 1.73 \\
\hline $\begin{array}{l}2.2 \\
2.6\end{array}$ & $\mathrm{BIX}$ & 0.83 & 0.79 & 0.82 \\
\hline 3 & HIX & 7.78 & 4.28 & 3.60 \\
\hline
\end{tabular}

Black Point

\begin{tabular}{|c|c|c|c|c|}
\hline Reef* & Reef & Diffuse & Transition & Spring \\
\hline 28.8 & 30.5 & 32.6 & 25.5 & 7.1 \\
\hline 2.8 & 3.2 & 16.6 & 106.8 & 626.9 \\
5.6 & 1.7 & 14.2 & 127.2 & 269.7 \\
0.14 & 0.23 & 1.16 & 21.15 & 114.16 \\
0.04 & 0.10 & 0.15 & 0.68 & 3.09 \\
\hline 0.26 & 0.34 & 0.52 & 0.94 & 0.22 \\
\hline 2280 & 2238 & 2263 & 2362 & 2824 \\
\hline 83.7 & 77.3 & 88.3 & 88.5 & 45.6 \\
\hline 5.7 & 6.1 & 6.6 & 6.6 & 33.6 \\
\hline 0.08 & 0.07 & 0.09 & 0.14 & 0.03 \\
\hline $3.2 \times 10^{5}$ & $3.7 \times 10^{5}$ & $2.3 \times 10^{5}$ & $2.2 \times 10^{5}$ & $1.0 \times 10^{5}$ \\
\hline $4.0 \times 10^{3}$ & $1.8 \times 10^{3}$ & $1.9 \times 10^{3}$ & $1.4 \times 10^{3}$ & $7.2 \times 10^{2}$ \\
\hline $6.0 \times 10^{3}$ & $4.9 \times 10^{3}$ & $5.2 \times 10^{3}$ & $6.8 \times 10^{3}$ & $5.4 \times 10^{3}$ \\
\hline 0.025 & 0.029 & 0.037 & 0.052 & 0.075 \\
0.029 & 0.034 & 0.043 & 0.062 & 0.091 \\
0.007 & 0.009 & 0.011 & 0.015 & 0.017 \\
\hline 0.016 & 0.017 & 0.021 & 0.027 & 0.023 \\
\hline 0.65 & 0.98 & 0.72 & 0.88 & 1.44 \\
\hline 1.02 & 1.01 & 1.03 & 1.07 & 1.20 \\
1.73 & 1.79 & 1.75 & 1.75 & 1.76 \\
0.80 & 0.84 & 0.83 & 0.82 & 0.85 \\
\hline 2.35 & 2.74 & 3.00 & 3.47 & 6.98 \\
\hline
\end{tabular}

Table 1. Mean values of each parameter in each of the biogeochemical provinces shaded according to magnitude of significant differences among regions. Rows are parameters, columns are biogeochemical provinces, and values are geometric means. Shaded cells are significantly different from the Ambient Reef (WL) province (denoted at top by *; Dunnet's post hoc test), with color and intensity scaled by mean log-ratio relative to Ambient Reef waters (legend at left). POC, PON and DOP are excluded due to a lack of data to properly test each province. 


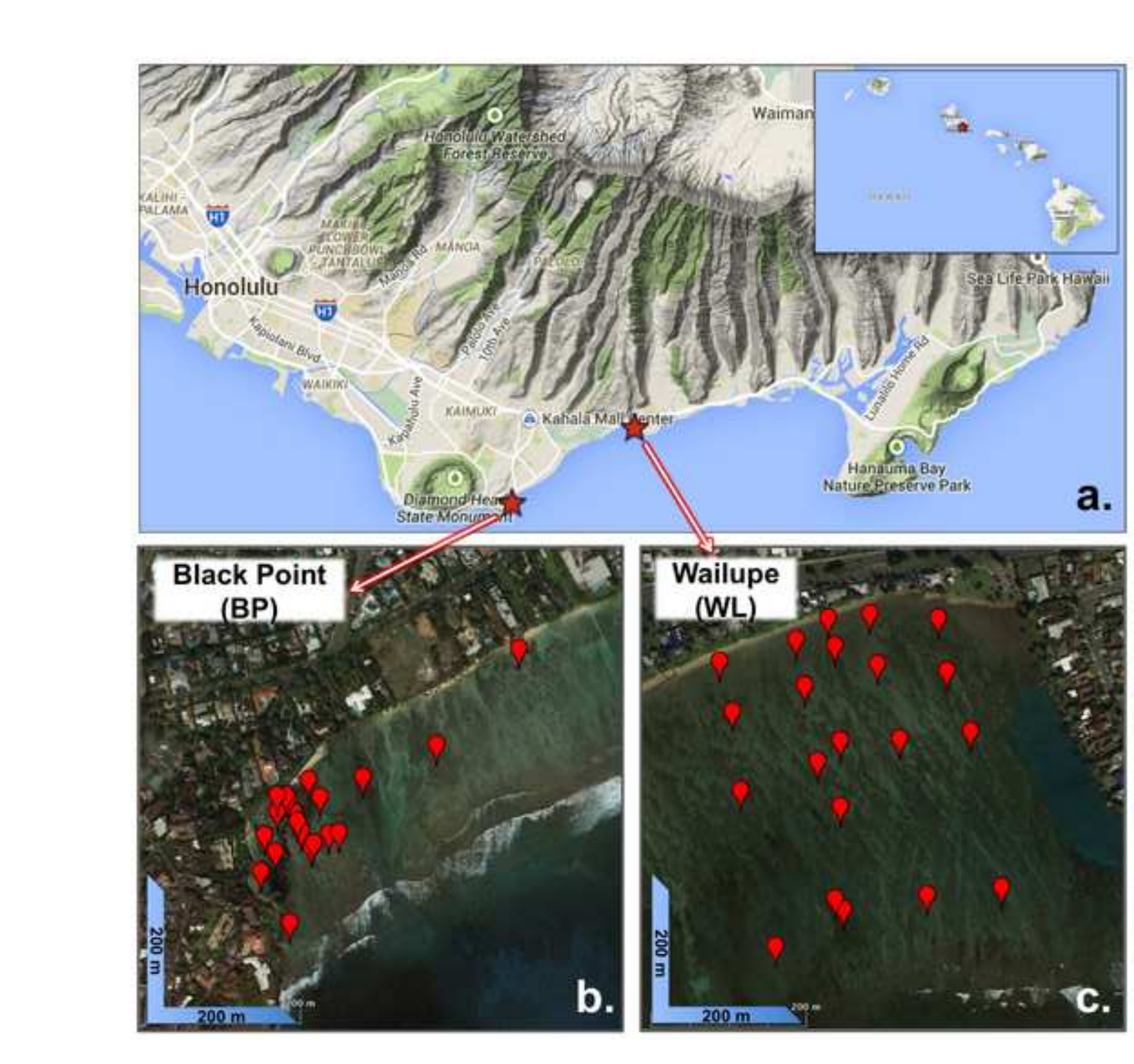

Hanauma Bay

Nature Breserve Park

a.

.

(n)

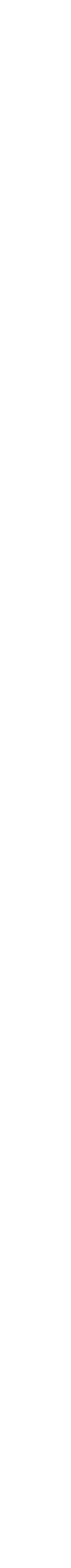

.
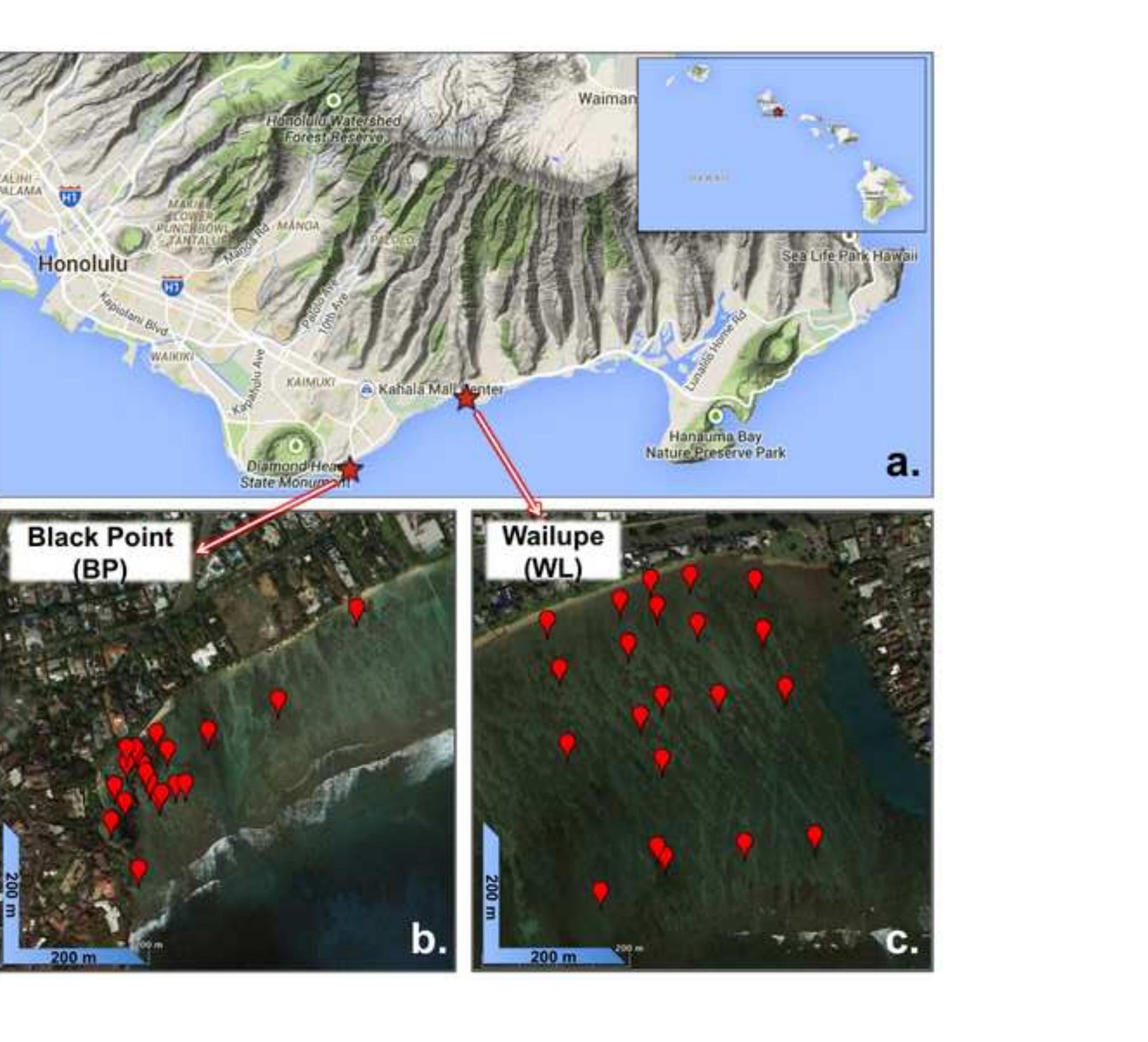
Black Point

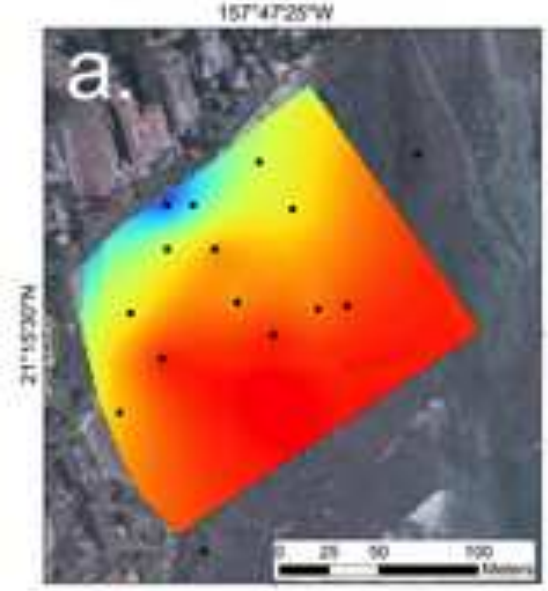

isturasw

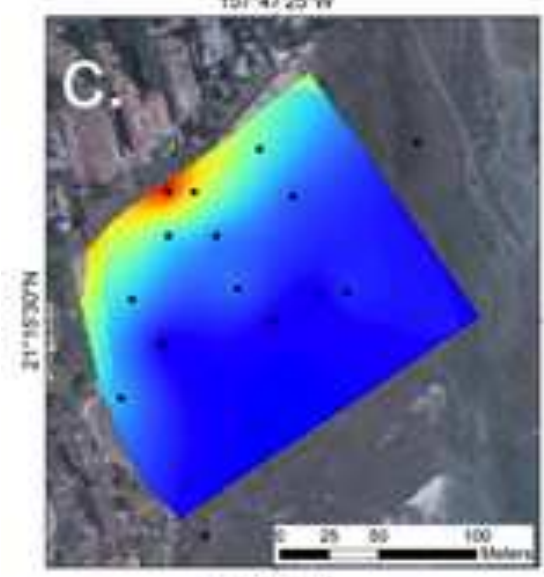

$18+4725 \mathrm{~W}$

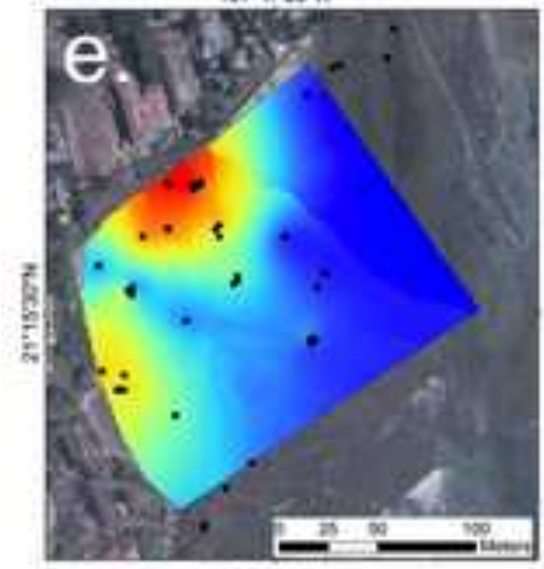

157.4785

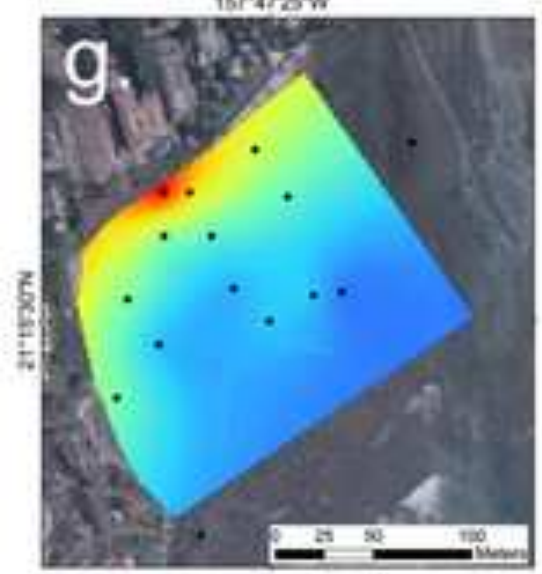

Wailupe
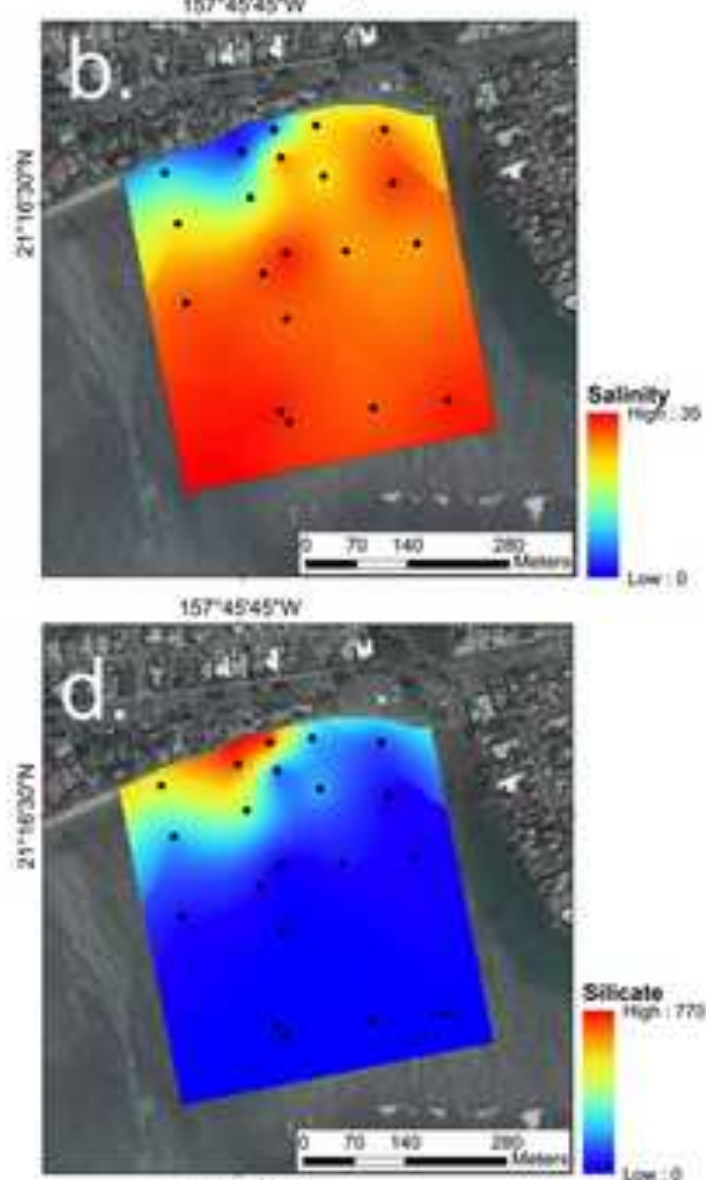

$15 T^{\circ} 4545 \mathrm{~W}$
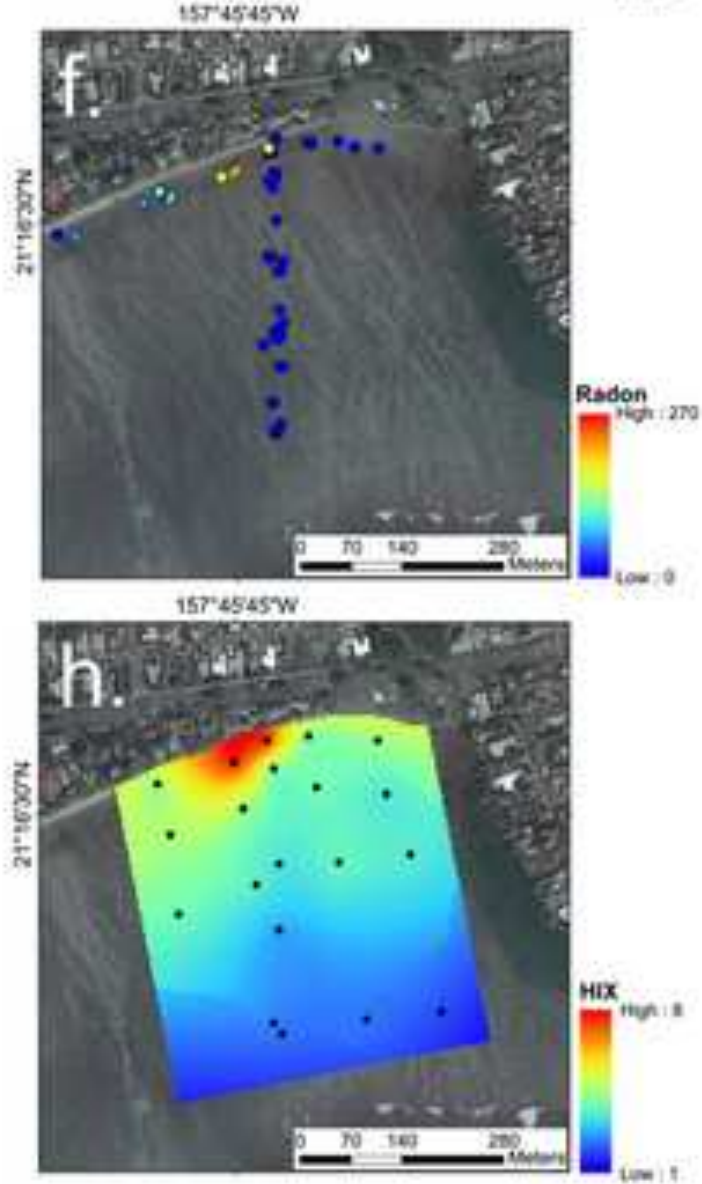

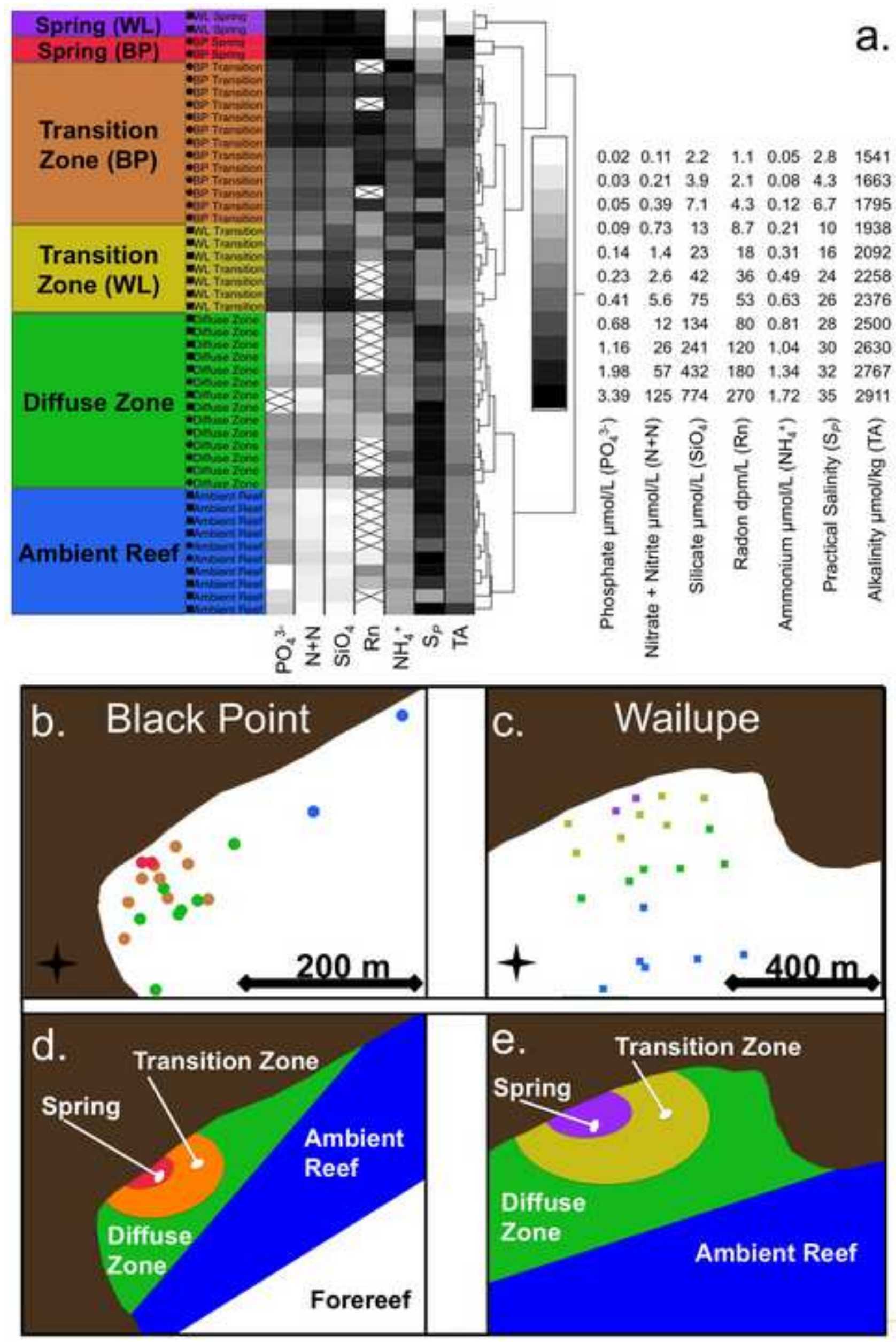


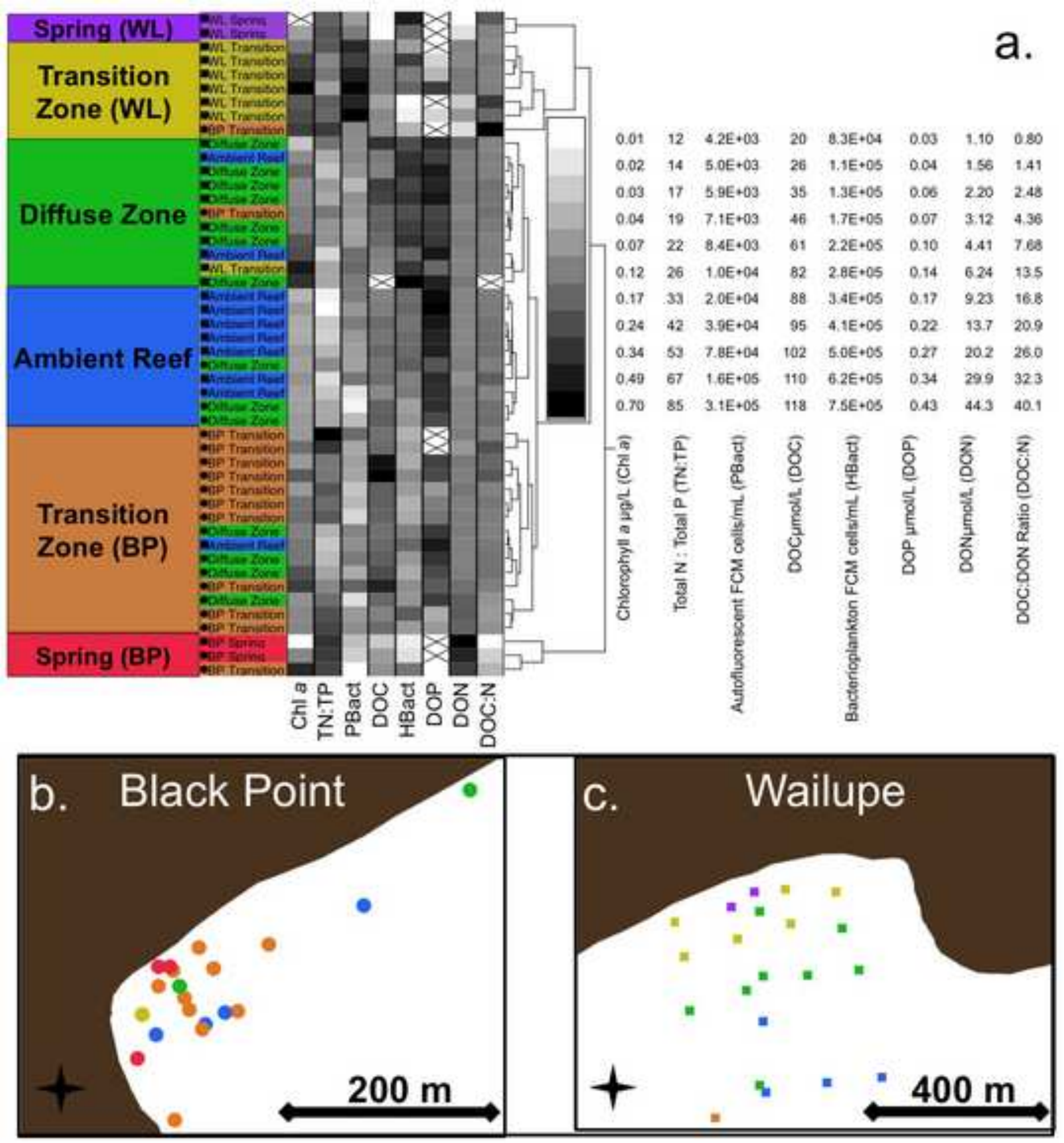




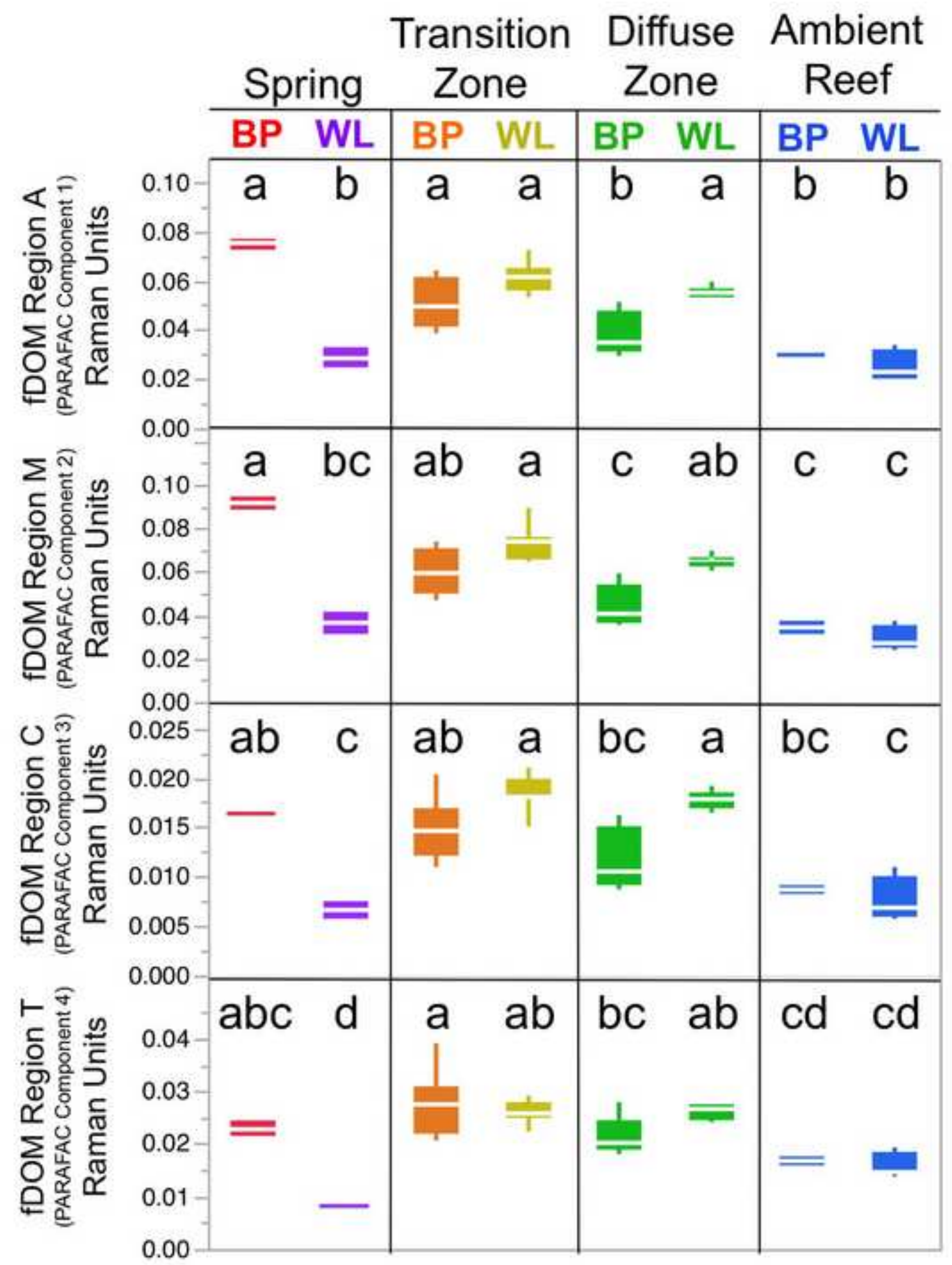




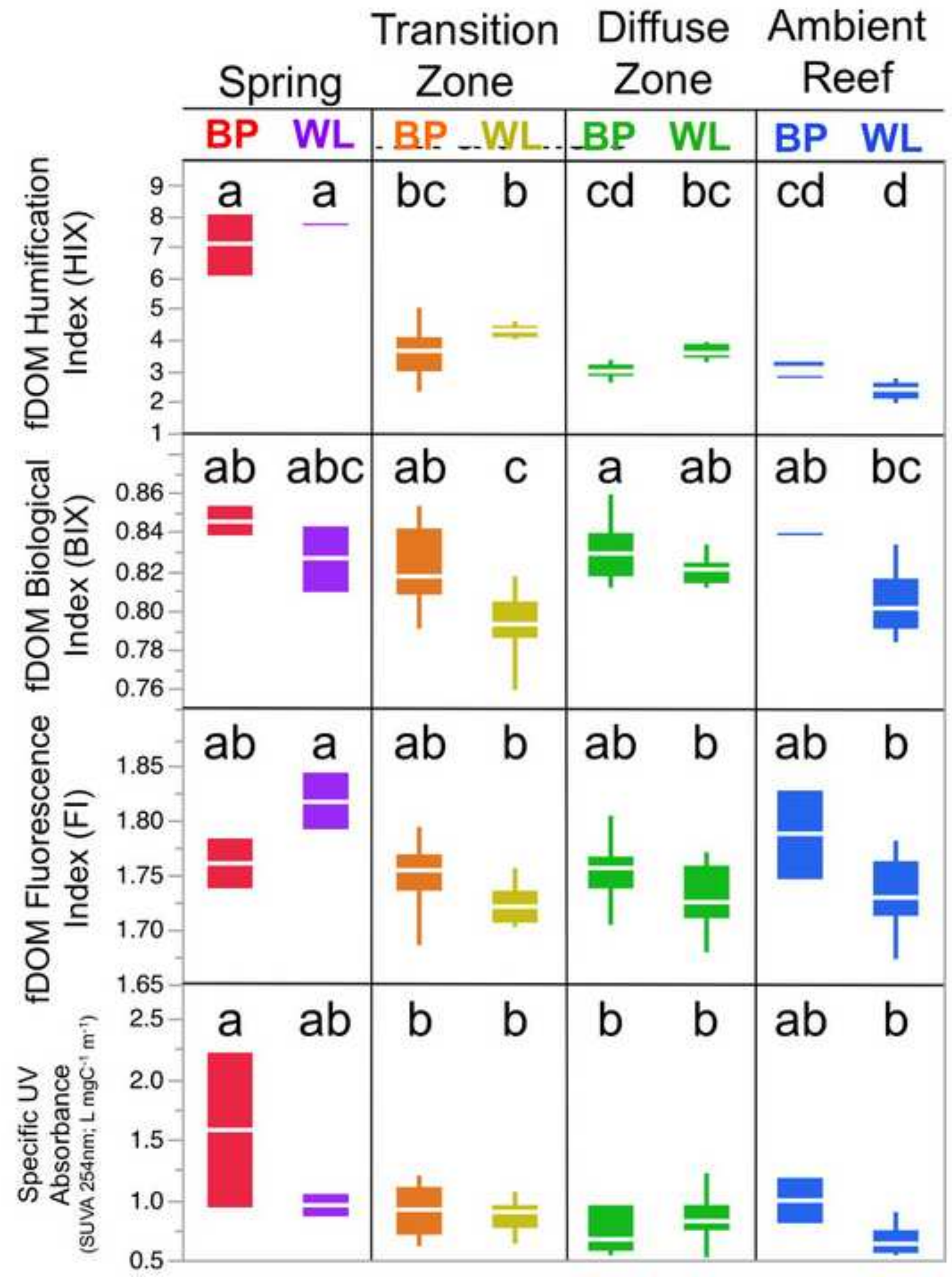




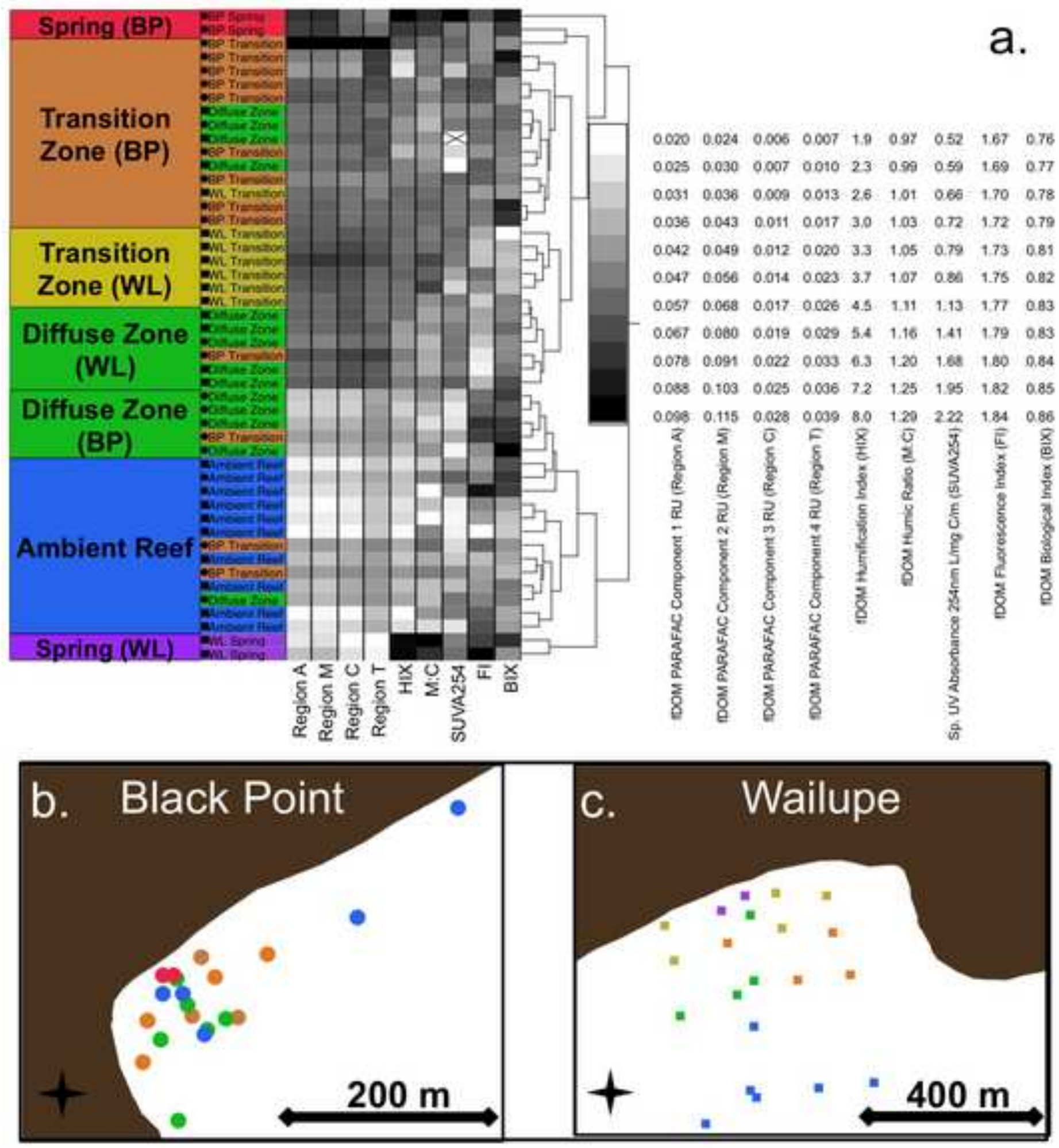

